\title{
Tetraselmis jejuensis sp. nov. (Chlorodendrophyceae), a Euryhaline Microalga Found in Supralittoral Tide Pools at Jeju Island, Korea
}

\author{
Jun-Ho Hyung ${ }^{1}$, Eun-Joo Kim ${ }^{1}$, Seung-Joo Moon ${ }^{1}$, Nam Seon Kang ${ }^{2, *}$ and Jaeyeon Park ${ }^{1, *} \mathbb{C}$ \\ 1 Environment and Resource Convergence Center, Advanced Institute of Convergence Technology, \\ Suwon 16229, Korea; hjh1120@snu.ac.kr (J.-H.H.); kej1005@snu.ac.kr (E.-J.K.); sjmoon04@snu.ac.kr (S.-J.M.) \\ 2 Department of Taxonomy and Systematics, National Marine Biodiversity Institute of Korea, \\ Seocheon 33662, Korea \\ * Correspondence: kang3610@mabik.re.kr (N.S.K.); bada0@snu.ac.kr (J.P.); Tel.: +82-41-950-0821 (N.S.K.); \\ +82-31-888-9042 (J.P.); Fax: +82-41-950-0811 (N.S.K.); +82-31-888-9040 (J.P.)
}

check for updates

Citation: Hyung, J.-H.; Kim, E.-J.; Moon, S.-J.; Kang, N.S.; Park, J.

Tetraselmis jejuensis sp. nov.

(Chlorodendrophyceae), a Euryhaline Microalga Found in Supralittoral Tide Pools at Jeju Island, Korea. Plants 2021, 10, 1289. https://doi.org/ $10.3390 /$ plants10071289

Academic Editors: Sousuke Imamura and Imran Pancha

Received: 3 June 2021

Accepted: 23 June 2021

Published: 24 June 2021

Publisher's Note: MDPI stays neutral with regard to jurisdictional claims in published maps and institutional affiliations.

Copyright: (c) 2021 by the authors. Licensee MDPI, Basel, Switzerland. This article is an open access article distributed under the terms and conditions of the Creative Commons Attribution (CC BY) license (https:// creativecommons.org/licenses/by/ $4.0 /)$.

\begin{abstract}
We found the euryhaline microalga, Tetraselmis jejuensis sp. nov., which was adapted to supralittoral tide pools with salinities varying from 0.3-3.1\%. Fifteen strains of T. jejuensis were isolated from Daejeong (DJ) and Yongduam (YO), and clonal cultures were established in the laboratory. Morphological characterization revealed that the cells have a compressed shape, four flagella emerging from a depression near the apex in two opposite pairs, a cup-shaped chloroplast containing one pyrenoid surrounded by starch, and eyespot regions not located near the flagellar base. T. jejuensis cells showed distinct characteristics compared to other Tetraselmis species. First, a regular subunit pattern with honeycomb-like structures was predominantly displayed on the surface in the middle of the cell body. Second, the pyrenoid was invaded by both cytoplasmic channels comprising electron-dense material separated from the cytoplasm, and two branches of small cytoplasmic channels (canaliculi) in various directions, which characterize the subgenus Tetrathele. Eyespot regions containing a large number of osmiophilic globules, packed closely together and arranged in subcircular close packing of diverse sizes, were dispersed throughout the chloroplast. In the phylogenetic analysis of small subunit (SSU) rDNA sequences, the 15 strains isolated from DJ and YO separated a newly branched clade in the Chlorodendrophyceae at the base of a clade comprising the T. carteriiformi/subcordiformis clade, T. chuii/suecica clade, and T. striata/convolutae clade. The strains in the diverging clade were considered to belong to the same species. The SSU rDNA sequences of the DJ and YO strains showed a maximum difference of $1.53 \%$ and $1.19 \%$ compared to Tetraselmis suecica (MK541745), the closest species of the family based on the phylogenetic analysis, respectively. Based on morphological, molecular, and physiological features, we suggest a new species in the genus Tetraselmis named Tetraselmis jejuensis, with the species name "jejuensis" referring to the collection site, Jeju Island, Korea.
\end{abstract}

Keywords: microalgae; Tetraselmis spp.; morphology; ultrastructure; salinity

\section{Introduction}

Marine microalgae have been recognized as promising resources for food supplements, cosmeceuticals, and biofuels [1-3]. For commercial applications, the establishment of mass cultivation systems is necessary for the selected monoculture microalgae. Open pond culture systems have been successfully used for mass cultivation because outdoor algal culture reduces the cost of culture maintenance and is easily controlled compared to indoor tanks or photobioreactors that require a large area, heating balance, and sterilization [4-7]. However, long-term cultures of microalgae in these systems are limited to a few species as they are exposed to extreme environments, such as varying salinity and nutrients due to evaporation or rainfall [8-10]. Thus, it is necessary to explore suitable microalgal species for successful monoclonal culture and under changing environmental conditions. 
Euryhaline marine microalgae, of the genus Tetraselmis, have been recently studied for efficient biofuel production [10-13]. They survive and maintain their robustness in outdoor culture conditions over a long period by controlling cytoplasmic ion homeostasis under severe osmotic stress by regulating ion concentrations $[7,10,14]$. The genus Tetraselmis is a member of Chlorodendrophyceae, a small class of green algal lineages that comprises marine and freshwater scaly quadriflagellates [15]. Traditionally classified within Prasinophytes, Chlorodendrophyceae are currently nested within the core Chlorophyta, including the Ulvophyceae, Trebouxiophyceae, and Chlorophyceae [16-18]. Phylogenetic analysis based on $18 \mathrm{~S}$ rDNA sequences indicates that Chlorodendrophyeceae belong to the core Chlorophyta as a deep diverging lineage [15,19-21]. As one of the key characteristics of the core Chlorophyta, cell division of Tetraselmis species is mediated by a phycoplast, including closed mitosis [22,23]. The morphological features of genus Tetraselmis are characterized by a compressed shape, four flagella of equal length emerging from a slit at the apical base, a single large chloroplast containing one pyrenoid and a conspicuous eyespot, and a nucleus that is parallel to the pyrenoid and flagellar base. Tetraselmis species are commonly found in estuaries, tide pools, and brackish ponds, where environmental fluctuations often occur because of rain storms, wave action, and evaporation [24,25].

The coastlines of Jeju Island are composed of basalt-based rocky shores. In supralittoral tide pools located above the high-tide line, several depressions formed by the vesicular textures of basalt are occasionally submerged, either under seawater from wave splash, winds, and storms, or under freshwater from heavy rainfall [26]. Microorganisms adapted to these habitats show high tolerance to extreme changes in salinity, temperature, and nutrient composition [27]. Although Tetraselmis gracilis isolated from the seawater of Jeju coast has been reported previously by [28], Tetraselmis species living in the supralittoral zone on Jeju Island have been much less explored. Moreover, traditional species circumscriptions can lead to species misidentification because diagnosis for cellular characterization is very complex, even though the morphological and ultrastructural characteristics of many Tetraselmis species have been well studied by light microscopic observations [29-31]. To prevent the commercial use of incorrect species, which could lead to economic losses, it is important to establish correct species assignments. Recently, ultrastructural investigations of species using electron microscopy have provided more distinctive features to allow species delimitation [22,32-36]. Phylogenetic analysis of species using DNA sequences has also presented useful taxonomic criteria to understand intraspecific variation and to identify similar species [37].

For collecting robust microalgae species, we investigated diverse sites with various environmental conditions, and about 50 strains of microalgae were collected. Among them, we first found a species of Tetraselmis adapted to the supralittoral tide pools on Jeju Island, and successfully established clonal cultures in the laboratory. Its morphological details and ultrastructure were investigated using light microscopy, scanning electron microscopy, and transmission electron microscopy. Molecular taxonomic identification of cells was performed by phylogenetic analysis based on the SSU rDNA sequences.

\section{Results}

\subsection{Morphological Analysis of Tetraselmis jejuensis}

Under light microscopy, the cells showed a compressed shape, flagella emerging from a depression at the apical base, a cup-shaped chloroplast which was yellow-green in color, and distinct creases that were parallel in the middle of the cell body (Figure 1a-c). The ovoid cells showed either a broad or narrow face in light micrographs. The anteroposterior (AP) length and width of the cells in the broad lateral view was 13.0-20.8 $\mu \mathrm{m}(16.7 \pm 2.5 \mu \mathrm{m})$, and $6.5-16.3 \mu \mathrm{m}(11.3 \pm 2.7 \mu \mathrm{m})$, respectively $(\mathrm{n}=40)$. The width from the narrow face corresponding to the depth in the broad view was 9.8-13.0 $\mu \mathrm{m}(11.7 \pm 0.8 \mu \mathrm{m}, \mathrm{n}=30)$ and was shorter than that in the broad lateral views. Light microscopic images using differential interference contrast (DIC) showed a scaly theca covering the cell body, a 
pyrenoid matrix located at the posterior part, and numerous orange-red eyespot regions dispersed throughout the chloroplast (Figure 1d-g).
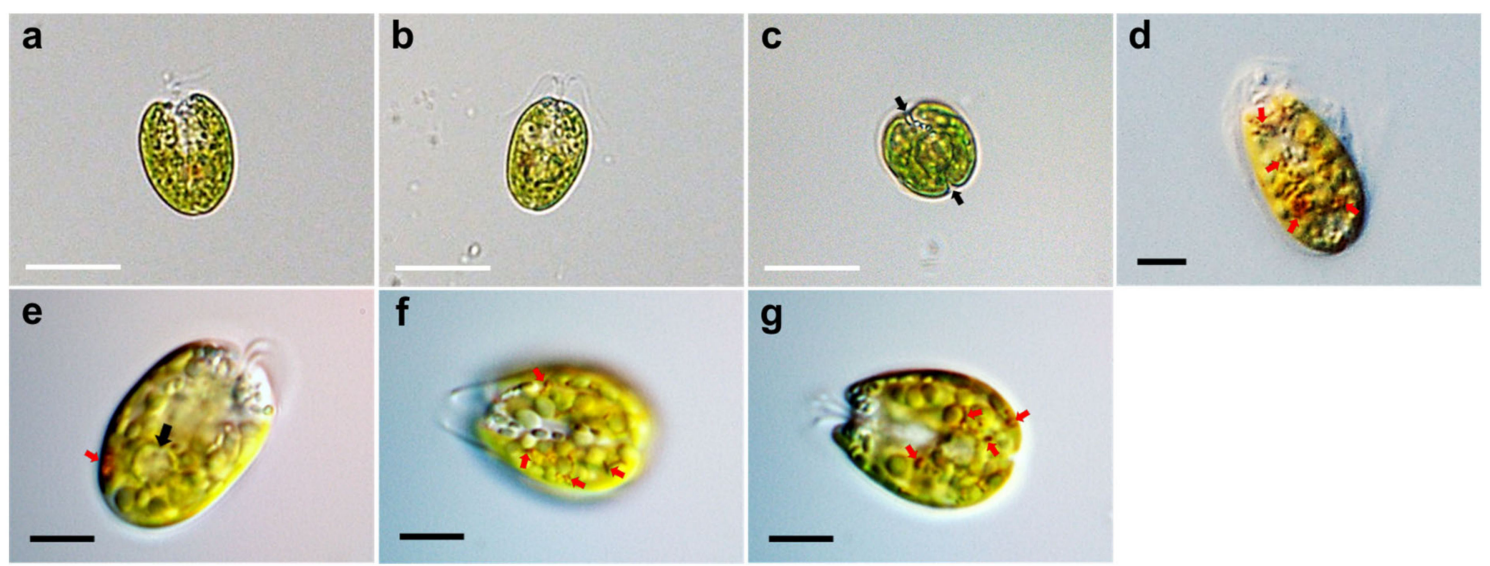

Figure 1. Micrographs of Tetraselmis jejuensis taken using light microscopy. (a) A broad lateral view, (b) a narrow lateral view, and (c) an antapical view of the cells. Two distinct creases are observed in the antapical view (black arrows). (d-g) Light microscopic images obtained using differential interference contrast (DIC). The scaly green flagellates showed a compressed shape, flagella attached to the bottom of the apical depression, a yellow-green colored chloroplast, pyrenoid matrix at the posterior part (black arrow), and conspicuous eyespot regions containing orange-red pigment granules (red arrows), spread out in the chloroplast. Scale bars (white) $=20 \mu \mathrm{m}$. Scale bars (black) $=5 \mu \mathrm{m}$.

The SEM micrographs of Tetraselmis jejuensis in the broad lateral view showed a slightly compressed shape, with four flagella emerging from a slit at the base of the apical depression, and distinct creases in the middle of the cell body (Figure 2a,b). The width of the apical depression was approximately $0.7-1.3 \mu \mathrm{m}$ (mean \pm standard deviation $=1.0 \pm 0.14 \mu \mathrm{m}, \mathrm{n}=20$ ). A deep-folded line in the middle of the cell body extended longitudinally from the apical depression to the posterior part of the cell. The linear crease was also observed in the middle when viewed from the narrow lateral side of the cells, but the apical depression was obscured from this view (Figure 2c,d). In the antapical view of the cells, some granular scales were spread over the cell surface, especially at the antapical side, and distinct creases in the middle were observed from each broad or narrow lateral side (Figure 2e,f). One crease from the lateral side was parallel to the other from the opposite side. As a common feature of motile cells of Tetraselmis species, the four flagella of the cells were arranged in two opposite pairs at the apical positions (Figure 2g,h and Figure 3a). In the magnified views of the flagella in the cells using SEM, the structure of the flagellar filaments was composed of thick, blunt-ended, and rod-shaped microtubules suitable for dynamic bending motions, and showed a fairly large number of thin pit hairs measuring approximately $0.2-0.8 \mu \mathrm{m}(0.5 \pm 0.13 \mu \mathrm{m}, \mathrm{n}=30)$ in length, attached to the stalks (Figure $3 \mathrm{~b}, \mathrm{c}$ ). Notably, most cells of Tetraselmis jejuensis contained regular subunit patterns on the cell surface near the posterior part adjacent to the middle furrow on the broad lateral side Figure $2 a, f$ and Figure $4 a, b)$. The magnified views of the SEM micrographs of the cells showed honeycomb-like structures in these patterns (Figure 2f), with a width of approximately $1.5 \mu \mathrm{m}$ (Figure 4c,d). 


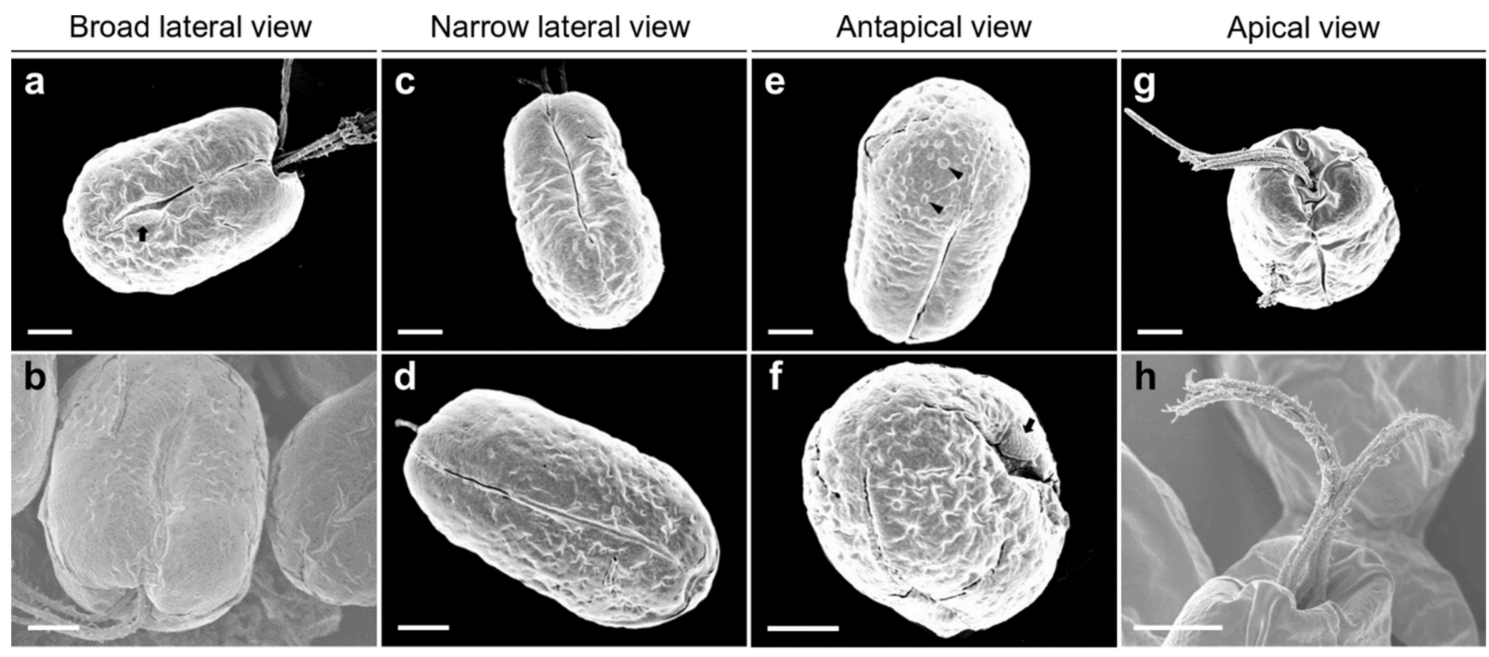

Figure 2. Micrographs of Tetraselmis jejuensis obtained using scanning electron microscopy. (a,b) Broad lateral views of cells showing depressions on the apical side. Distinct creases in the middle, and a regular subunit pattern (black arrow) on the cell surface adjacent to the middle furrow were observed. (c,d) Narrow lateral views of cells containing deep folded lines in the middle. Depressions were obscured from the apical peaks. (e,f) Antapical views of cells showing granular scales on the surface (black arrowheads). A regular subunit pattern was exhibited on the surface near the furrow (black arrow). $(\mathbf{g}, \mathbf{h})$ Apical views of the cells showing four flagellar hairs in 2 opposite pairs. Scale bars $=2 \mu \mathrm{m}$.
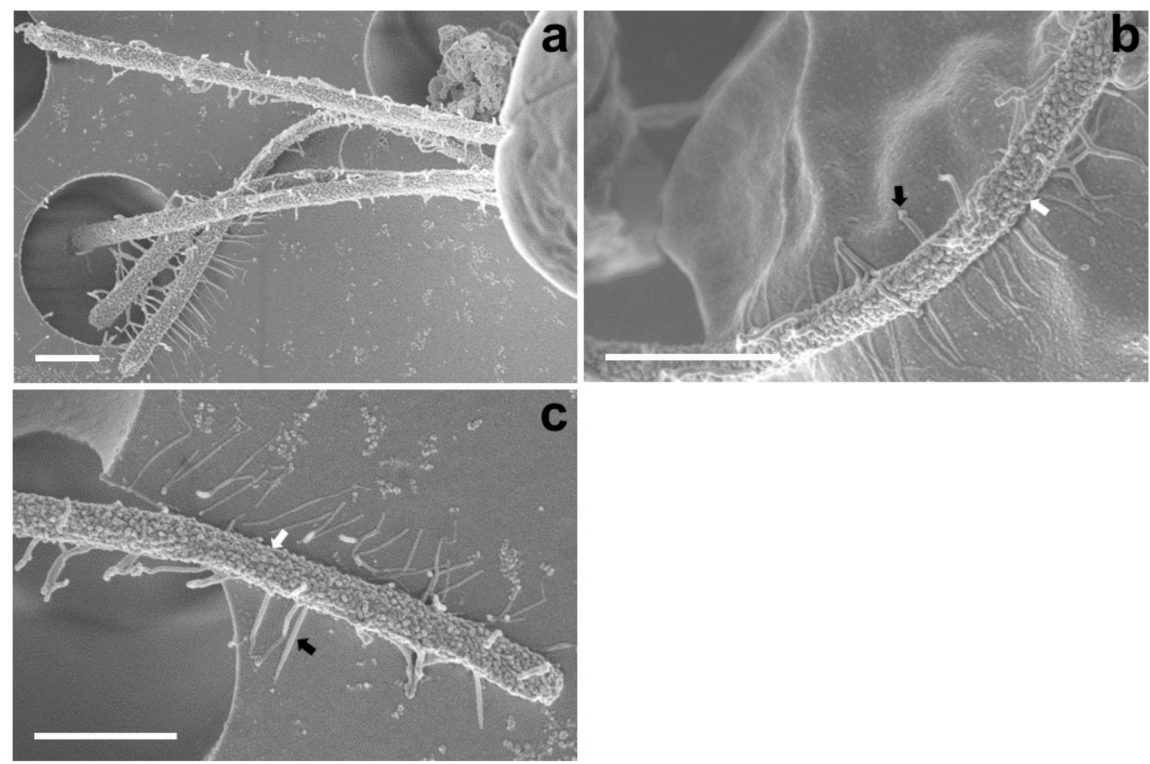

c

Figure 3. Micrographs of the flagella in Tetraselmis jejuensis obtained using scanning electron microscopy. (a) Four flagella were observed at the bottom of the cell body. (b,c) Structure of the cell flagella; microtubules showing thick, rod-shaped, and blunt-ended stalks (white arrows) and thin pit hairs (black arrows). Scale bars $=1 \mu \mathrm{m}$. 


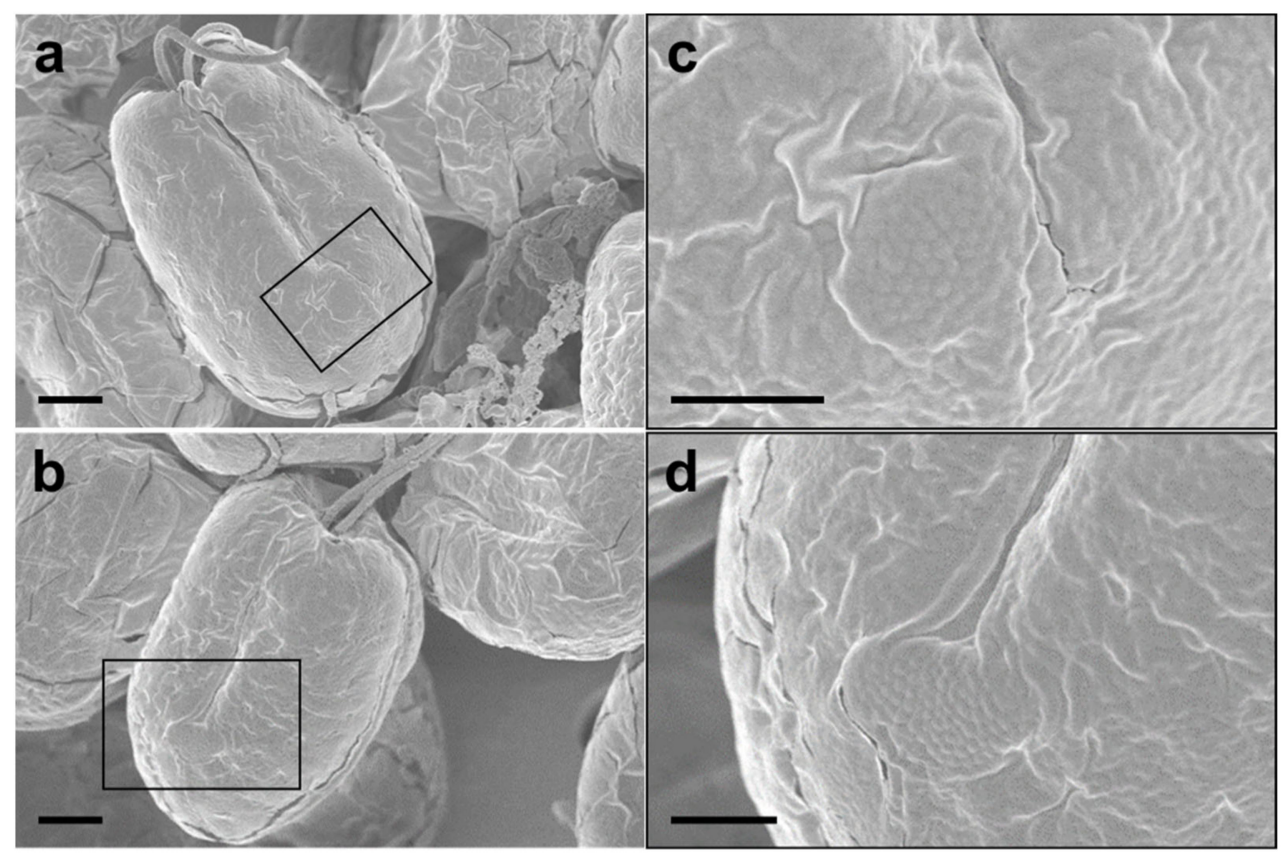

Figure 4. Regular subunit patterns and honeycomb-like structures observed in SEM micrographs of Tetraselmis jejuensis. (a,b) The unique patterns are observed in the broad lateral views. (c,d) Magnified views of regions highlighted by black squares in the adjacent panels. Scale bars $=2 \mu \mathrm{m}$ for (a), (b). Scale bars $=1 \mu \mathrm{m}$ for $(\mathbf{c}, \mathbf{d})$.

\subsection{Ultrastructural Characterization of Tetraselmis jejuensis}

TEM images of the longitudinal and transverse sections of Tetraselmis jejuensis cells showed the following cell organelles: a cup-shaped chloroplast enclosed in the outer plate membrane, a large vacuole, golgi apparatus, several starch granules, mitochondria, numerous eyespot globules, a pyrenoid, and a nucleus mostly observed on the left side near the upper part of the cell (Figure $5 \mathrm{a}, \mathrm{c}$ ). In the longitudinal sections of the cells, the pyrenoid was located in the basal position of the cell body and was embedded in the chloroplast (Figure $5 \mathrm{a}, \mathrm{b}$ ). The length and width of the pyrenoid in longitudinal sections were 1.3-4.0 $\mu \mathrm{m}(2.7 \pm 1.0 \mu \mathrm{m})$, and 2.0-5.2 $\mu \mathrm{m}(3.6 \pm 1.0 \mu \mathrm{m})$, respectively, measured by TEM micrographs $(n=20)$. The pyrenoid matrix of the cells was surrounded by a starch sheath, in which each granule showed a plate shape (Figure 5a,c). In both longitudinal and transverse sections of T. jejuensis cells, the matrix was invaded by cytoplasmic channels comprising electron-dense material separated from the cytoplasm and by small cytoplasmic channels (canaliculi) in various directions (Figure 5a,c). The large pyrenoid cavity opened towards the nucleus, but there were no intervening thylakoid membranes between the starch sheaths and the pyrenoid. These structures of the pyrenoid matrix were clearly visualized by serial TEM micrographs proceeding from the apical to the antapical region of the cells. In addition to a cavity invading the central pyrenoid, another cavity was observed in the matrix near the posterior region (Figure 6). 


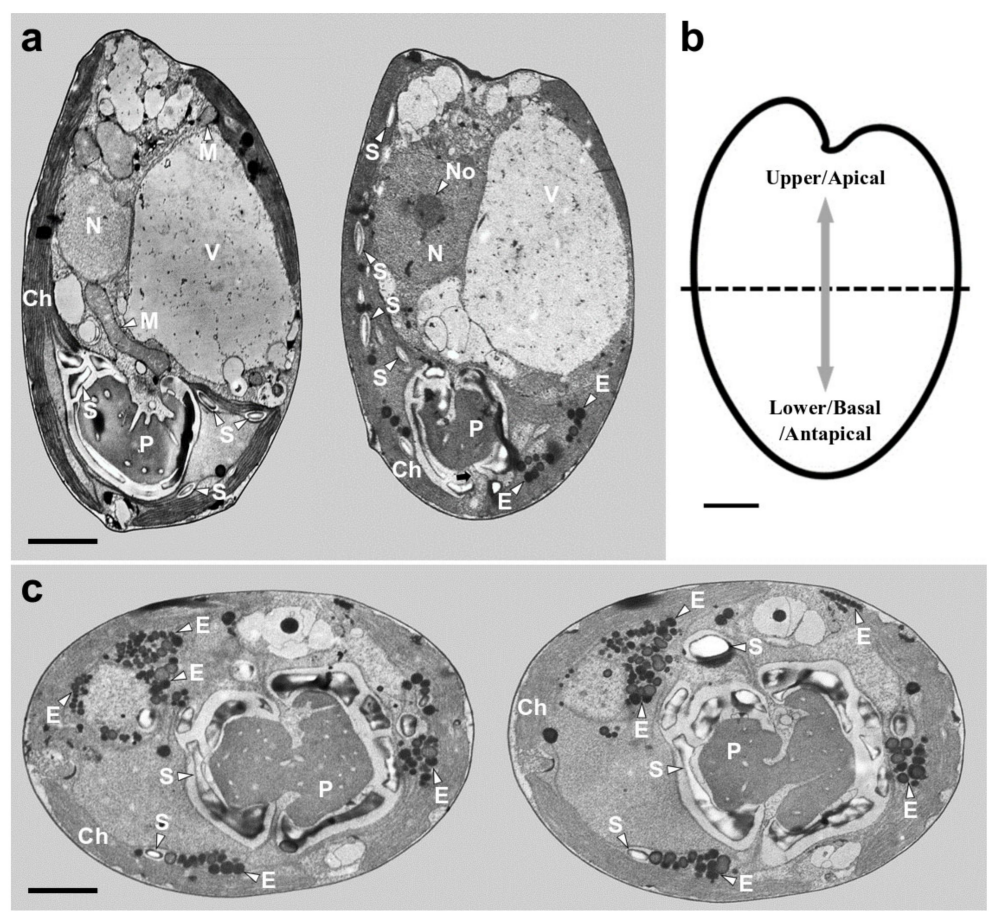

Figure 5. Micrographs of Tetraselmis jejuensis obtained using transmission electron microscopy. (a) Longitudinal sections showing several organelles inside the protoplasm, including chloroplasts $(\mathrm{Ch})$, eyespot granules $(\mathrm{E})$, mitochondria $(\mathrm{M})$, nucleus $(\mathrm{N})$, nucleolus $(\mathrm{No})$, pyrenoid $(\mathrm{P})$, starch $(\mathrm{S})$, and vacuoles $(\mathrm{V})$. The pyrenoid was invaded by both cytoplasmic channels comprising electron-dense material separated from the cytoplasm and canaliculi traversing it in opposite directions (black arrow). (b) Schematic drawing of longitudinal section indicating the upper/apical and lower/basal/antapical positions. (c) Transverse sections showing the position and structure of chloroplast (Ch), eyespot granules $(\mathrm{E})$, pyrenoid $(\mathrm{P})$, and starch $(\mathrm{S})$. Scale bars $=2 \mu \mathrm{m}$.
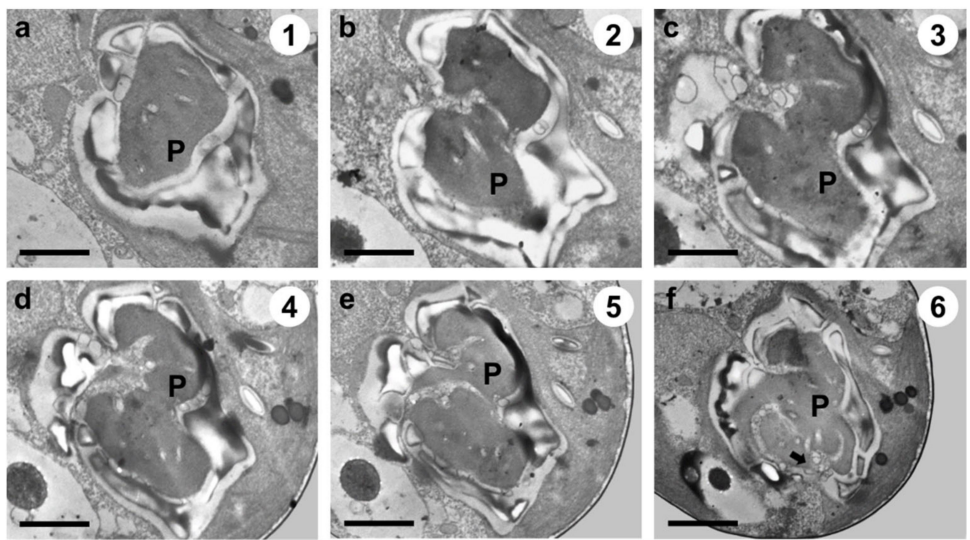

Figure 6. Serial TEM micrographs for the visualization of the pyrenoid matrix $(\mathrm{P})$ of Tetraselmis jejuensis, which was penetrated by cytoplasmic channels (canaliculi) in various directions. The serial sections were obtained from the apical to the antapical direction in the cell. (a) The pyrenoid was encased in a starch sheath in the upper part. (b-e) It was invaded by canaliculi in the middle part. (f) Another penetration of cytoplasmic materials from a different direction was observed in the pyrenoid in the lower part (black arrow). The circled number in each micrograph indicates the section number in a series of sections. Scale bars $=1 \mu \mathrm{m}$.

Under TEM, magnified views of cellular ultrastructures showed that a pyrenoid was embedded in the chloroplast (Figure 7a); a round-shaped nucleus with a distinct nucleolus related to ribosome synthesis was encased by bilayer membranes and the nucleus was 
located near the flagellar base (Figure $7 \mathrm{~b}, \mathrm{~h}$ ); starch granules were sandwiched between thylakoid membranes of the chloroplast, and mitochondria were scattered throughout the cytoplasm in the cells (Figure 5a and Figure 7c). A large number of eyespots (stigmas) were mostly positioned in the lower part of the cell body, especially near the antapical base. Each eyespot contained a large number of osmiophilic globules, which tended to be packed close together and were arranged in subcircular close packing of diverse sizes (Figure 5a,c and Figure 7d). A cross-sectional image of the flagellar base showed a flagellar apparatus including the microtubule structure of the basal bodies, rhizoplast connecting the basal bodies to the nucleus, and Golgi bodies encircling the basal complex (Figure 7e,h). Notably, basal bodies connecting the flagellar filaments to the cell body were embedded in the flagellar apertures, and the slit width was approximately $0.23-0.34 \mu \mathrm{m}$ (Figure $7 \mathrm{f}-\mathrm{h}$ ). Adhesive junctions, called half-desmosomes, which affix each flagellar basal body to the cell membranes, and flagella pit hairs located on the floor of the apical depression were also observed in the cells (Figure 7f,g).

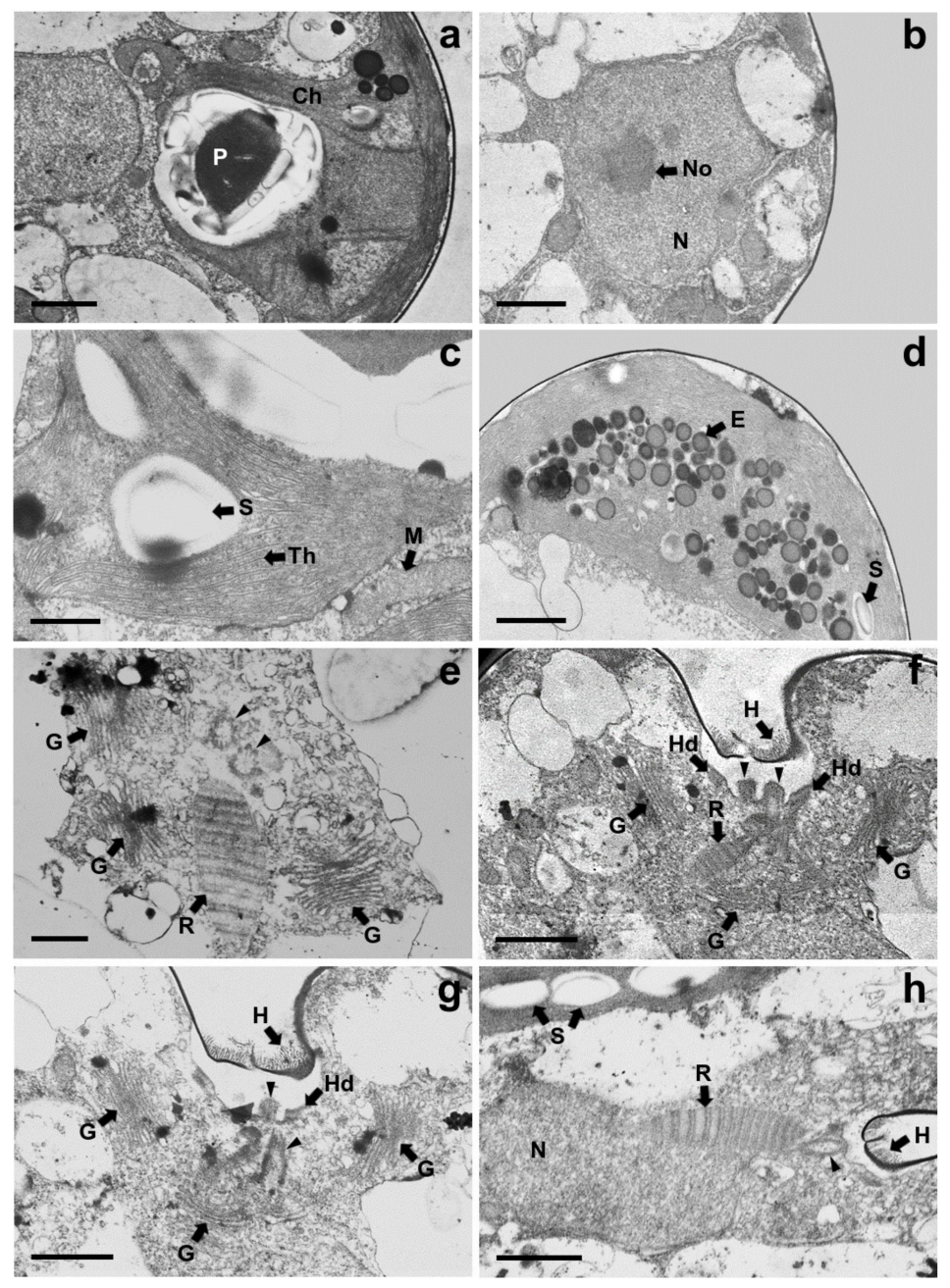

Figure 7. Magnified views of TEM micrographs of Tetraselmis jejuensis showing the position of cell organelles: (a) chloroplast $(\mathrm{Ch})$ and pyrenoid $(\mathrm{P}) ;(\mathbf{b})$ nucleus $(\mathrm{N})$ and nucleolus $(\mathrm{No}) ;(\mathbf{c})$ mitochondria (M), starch (S), and thylakoid membranes (Th); (d) Eyespot granules (E); (e-h) Flagellar apparatus of the cells; Flagella pit hairs (H), Golgi bodies $(\mathrm{G})$, half-desmosome (Hd), rhizoplast (R), and basal bodies (black arrowheads). Scale bars $=1 \mu \mathrm{m}$ for $(\mathbf{a}, \mathbf{b}, \mathbf{d}, \mathbf{f}-\mathbf{h})$. Scale bars $=500 \mathrm{~nm}$ for $(\mathbf{c})$ and $(\mathbf{e})$.

\subsection{Morphological Characterization of Tetraselmis jejuensis at Different Life Stages}

During periods of unfavorable conditions or reproduction, flagellated cells (Figure 8a,b) are transformed into resting cells, and cysts are displayed in the resting phase of the cell 
cycle. In SEM micrographs, these resting cells were encapsulated by a smooth theca with a short papilla and lost their flagella (Figure 8c-e). Under light microscopy, a non-motile cell without the four flagella was enclosed with a single or bilayer membrane showing a very small aperture (Figure $8 \mathrm{f}, \mathrm{g}$ ). In the process of vegetative reproduction, Tetraselmis jejuensis cells underwent asymmetric cell division, resulting in morphological differences between daughter cells and heterogeneity within clonal cells. The two pyrenoids separated by cell division showed asymmetric properties (Figure $8 \mathrm{~h}, \mathrm{i}$ ). The protoplasts of two daughter cells transversely divided in the parent cell wall were different in morphology and ultrastructure (Figure 8j,k).

\section{Flagellated stage}
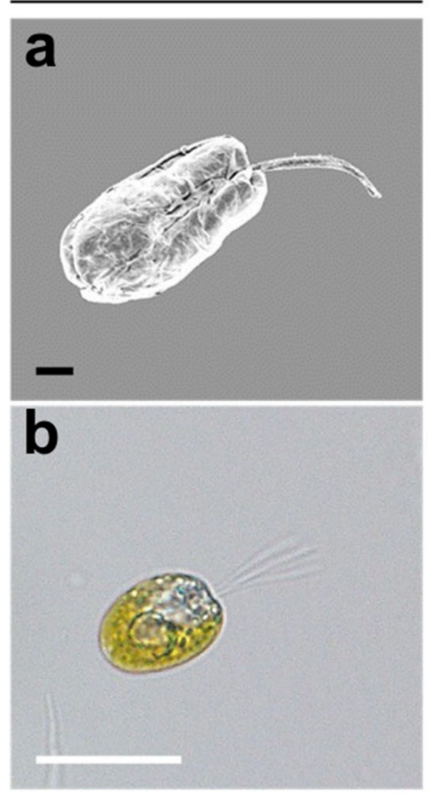

Resting stage
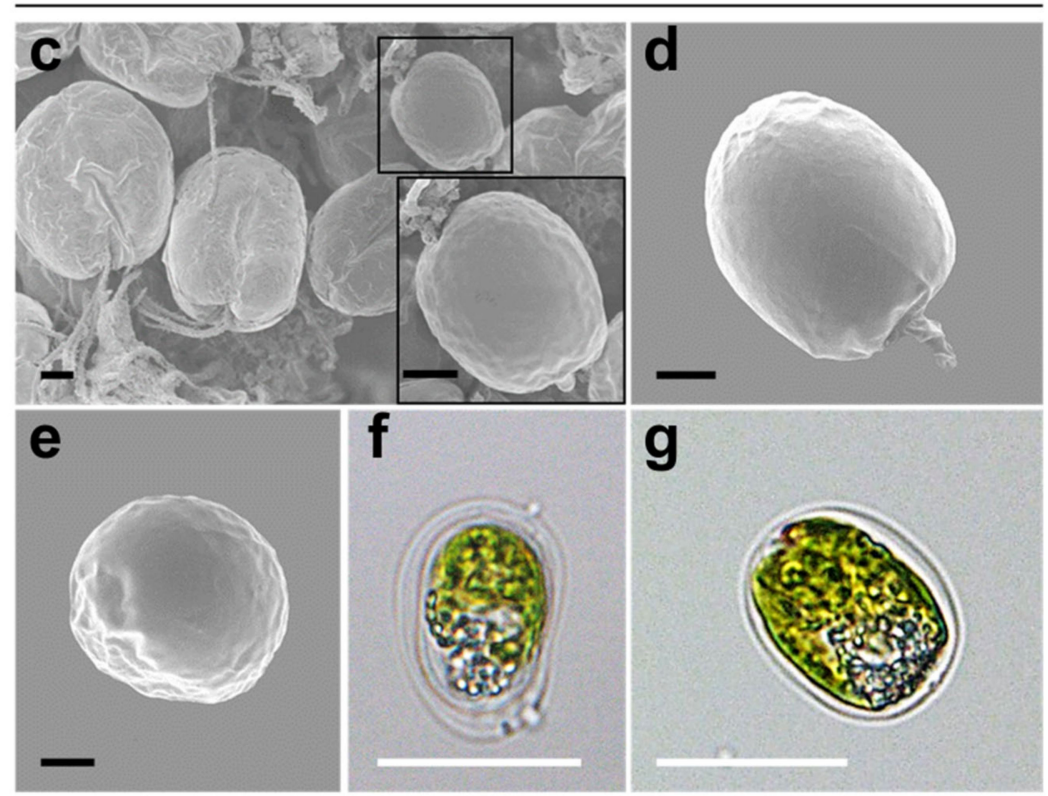

Cell division
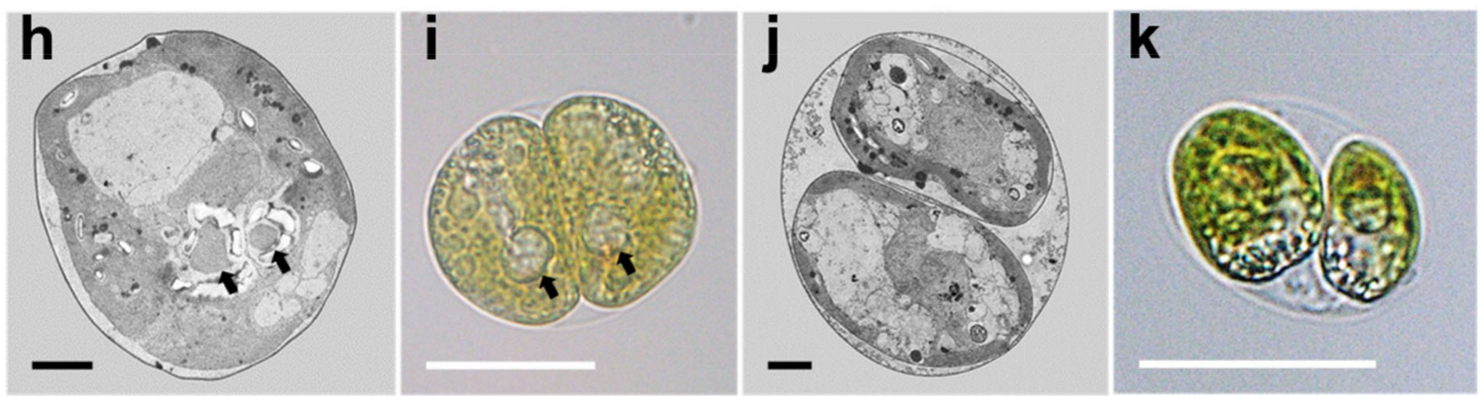

Figure 8. Morphological characteristics of Tetraselmis jejuensis in various life stages. (a,b) Motile cells, present in the flagellated stage. Resting cells were formed in response to stressful conditions or cellular reproduction. (c) Scattered cells including a resting cell highlighted by a black square, along with its magnified view. (d) Lateral, and (e) apical views of the resting cell. $(\mathbf{f}, \mathbf{g})$ Non-motile cells surrounded by single or bilayer membranes. (h-k) Asymmetric cell division in the process of vegetative reproduction; separated pyrenoids were observed (black arrows). Micrographs were obtained using $\operatorname{SEM}(\mathbf{a}, \mathbf{c}, \mathbf{d}, \mathbf{e}), \operatorname{TEM}(\mathbf{h}, \mathbf{j})$, and light microscopy $(\mathbf{b}, \mathbf{f}, \mathbf{g}, \mathbf{i}, \mathbf{k})$. Scale bars (black) $=2 \mu \mathrm{m}$. Scale bars (white) $=20 \mu \mathrm{m}$.

\subsection{Phylogenetic Analysis of Tetraselmis jejuensis}

The SSU rDNA sequences of 16 Tetraselmis jejuensis strains were determined by PCR amplification, and ranged from 1514 to $1631 \mathrm{bp}$. We investigated phylogenetic relationships based on SSU rDNA sequences between T. jejuensis and other Tetraselmis species deposited in GenBank. A maximum likelihood (ML) tree for 70 candidates showed that the 16 isolated 
strains of Tetraselmis species were positioned in the class Chlorodendrophyceae (Figure 9). Of these, 15 strains formed a newly branched clade, with $86 \%$ bootstrap value in the class. Only the Tetraselmis sp. YO 2 strain, found at a salinity of 3.9\%, was included in the Tetraselmis carteriiformis/subcordiformis clade, with a $97 \%$ bootstrap value. For phylogenetic relationships based on the ML tree of SSU rDNA, the isolated strains in this study were relatively closer to the Tetrasemis carteriiformi/subcordiformis clade, Tetrasemis chuii/suecica clade, and the Tetrasemis striata/convolutae clade than to the early diverging clades in the family, such as Tetraselmis marina, Tetraselmis astigmatica, Tetraselmis indica, and others.

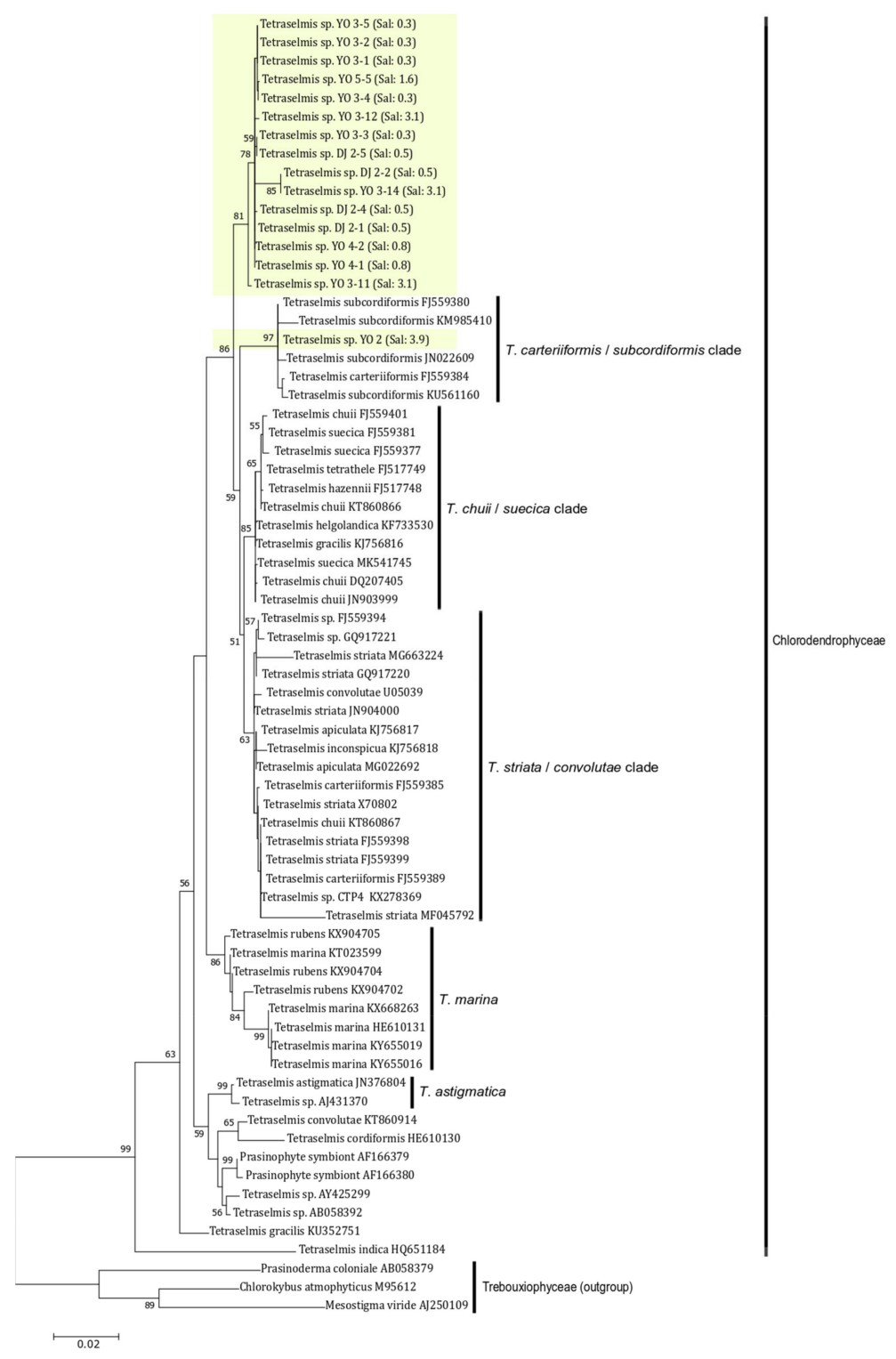

Figure 9. Phylogenetic analysis of Tetraselmis jejuensis using a Maximum-likelihood (ML) tree of the SSU rDNA sequences. Fifteen strains of T. jejuensis from this study formed a separate branch in the Chlorodendrophyceae except for one strain found at a salinity of 3.9\%. ML bootstrap values $(>50)$ are shown next to the branches. Scale bar $=$ the number of nucleotide substitutions per site.

\section{Discussion}

Supralittoral tide pools made of basalt on the Jeju Island coastline have varying salinities, ranging from $0.1-10 \%$. These extreme changes in salinity in these tide zones are caused by the precipitation, evaporation, and varying environmental conditions on Jeju Island. In these areas, rain pools with very low salinity levels existed in the area near 
the land, and the pool near the sea had a salinity similar to that of seawater. A salinity gradient had occurred between the two regions, and sometimes the pool with a very high salinity was formed by evaporation. Therefore, the salinity of each pool varied depending on rainfall, evaporation, and waves, but the salinity of the rain pools existing near the land, which the breaking waves could not influence, were maintained relatively low.

In this study, we found the euryhaline microalga, Tetraselmis jejuensis, in two supralittoral tide pools on Jeju Island: Yongduam (YO) in the north, and Daejeong in the south. Collected cells were found to naturally survive in the supralittoral zones with a wide salinity range from $0.3-3.1 \%$ (Figure 11 and Table 3). Tetraselmis suecica and Tetraselmis tetrathele, which are widely known euryhaline species, are used as feedstock, and require salinities of $2.0-6.0 \%$ and $3.0-3.5 \%$ for their growth, respectively $[38,39]$. Tetraselmis sp. CTP4 strains could be cultivated at salinities ranging from $0.5-3.6 \%$ [13], and the optimal growth of Tetraselmis gracilis strains found on the Jeju coast with regard to salinity changes ranged from $2.0-2.5 \%$ [28]. However, robustness to various salt concentrations was evaluated by the manipulation of salinity in the laboratory-cultured medium. Thus, the physiological characteristics of $T$. jejuensis are distinct compared to those of other Tetraselmis species reported previously, and an optimal salinity of less than $1.0 \%$ for the growth of Tetraselmis species has been rarely reported. The morphological characteristics of the genus Tetraselmis have been well studied by many researchers for taxonomic identification $[22,31-35,40]$. The new species, $T$. jejuensis, shares these taxonomic characteristics with the genus Tetraselmis. Its cells are elliptically shaped and covered by a scale-based theca with four emerging equal flagella from the apical depression. The nucleus lies close to the flagellar apparatus, and a cup-shaped chloroplast includes eyespot regions and one pyrenoid inside the cell protoplasm. The pyrenoid is surrounded by starch and is embedded in the chloroplast.

Comparing the morphological and ultrastructural features between T. jejuensis and other Tetraselmis species reported in previous studies, we found several characteristics of T. jejuensis by light microscopy, SEM, and TEM (Table 1). First, distinct creases were observed in the middle of the cell body in both the broad and narrow lateral views (Figures $1 \mathrm{c}$ and 2a-f). As previously reported by [22,31], these creases are not key for classifying the species of T. jejuensis. However, micrographs clearly showing these furrows on the cell surface have been rarely presented so far, including the above results obtained using light microscopy and a vaguely visualized SEM micrograph, respectively. According to [41], Tetraselmis indica cells contain creases that divide the cell into longitudinal sections, but these creases are observed only in the broad face of the cells. Second, some scale particles were particularly spread out on the surface at the antapical side of the cells (Figure 2e,f). Recently, [41] reported that these kinds of cells are observed on the cell surface of Tetraselmis indica, with a maximum scale size of $1.08 \mu \mathrm{m}$, in agreement with the measurements in this study. However, these shapes and sizes varied between different species; T. indica particles exhibited a hollow rim shape, whereas those of T. jejuensis showed a shallow dent-like structure, with a maximum depth of $0.58 \mu \mathrm{m}$ in the cells. Notably, we found, by SEM, distinct patterns containing honeycomb-like structures in the middle of the broad lateral side of T. jejuensis (Figure 2a,f and Figure 4). It is thus important to determine whether Tetraselmis species with or without these patterns belong to T. jejuensis, because this pattern has rarely been reported so far. It would thus be worthwhile to examine whether other Tetraselmis species have such honeycomb-like structures. 


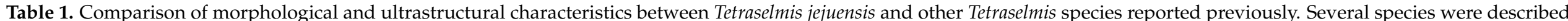
before the emergence of electron microscopy. ND, information not available.

\begin{tabular}{|c|c|c|c|c|c|c|c|c|c|c|}
\hline Species & $\begin{array}{l}\text { Location and Type of } \\
\text { Habitat }\end{array}$ & Cell Shape and Size & Regular Subunit Pattern & $\begin{array}{l}\text { Specific Scales on the } \\
\text { Cell Surface }\end{array}$ & $\begin{array}{l}\text { Pyrenoid Matrix and } \\
\text { Subgenus }\end{array}$ & Eyespot (Stigma) & Nuclear Position & Chloroplast & Golgi Bodies & References \\
\hline Tetraselmis jejuensis & $\begin{array}{l}\text { Jeju Illand, Korea; } \\
\text { supralittoral tide pools }\end{array}$ & $\begin{array}{c}\text { Compressed, ellipitical, } \\
\text { and four creases } \\
\text { obbiously showing in } \\
\text { both broad and narrow } \\
\text { lateral views; } 133.0-20.8 \times \\
6.5-16.3 \times 9.8-13.0 \mu \mathrm{m}\end{array}$ & $\begin{array}{l}\text { Observed, } \\
\text { honeycomb-like structure }\end{array}$ & $\begin{array}{c}\text { Observed, a shallow } \\
\text { dent-like shape, } \\
\text { measuring a maximum of } \\
0.58 \mu \mathrm{m}\end{array}$ & $\begin{array}{l}\text { Present in the lower part } \\
\text { of the cell body adjacent } \\
\text { to the antapicial base, } \\
\text { surrounded by starch } \\
\text { plates; Tetrathele }\end{array}$ & $\begin{array}{l}\text { Numerous eyespot } \\
\text { globules, mostly located } \\
\text { on the lower part of the } \\
\text { cell body and spread out } \\
\text { in the chloroplast }\end{array}$ & $\begin{array}{l}\text { Located in the upper part } \\
\text { of cell body near the } \\
\text { flagellar base }\end{array}$ & $\begin{array}{l}\text { Cup shaped, enclosed by } \\
\text { the outer plate membrane }\end{array}$ & $\begin{array}{l}2-4, \text { around the flagellar } \\
\text { base }\end{array}$ & This study \\
\hline T. alacris & $\begin{array}{l}\text { Europe and North } \\
\text { America; rock pools }\end{array}$ & $\begin{array}{c}\text { Compressed, broadly } \\
\text { ovoid; } 9.5-12 \times 8.0-8.5 \times \\
6.5-7.0 \mu \mathrm{m}\end{array}$ & ND & ND & $\begin{array}{l}\text { Small, spheroidal, central, } \\
\text { surrounded by } \\
\text { concave-convex } \\
\text { grains; } \text { Parvisiselmis }\end{array}$ & $\begin{array}{l}\text { Inconspicuous, located } \\
\text { around the pyrenoid }\end{array}$ & Central & $\begin{array}{l}\text { Finely lobed in the } \\
\text { posterior }\end{array}$ & $\begin{array}{l}\text { 2, around the flagellar } \\
\text { base }\end{array}$ & {$[31,35]$} \\
\hline T. apiculata & France; estuaries & $\begin{array}{c}\text { Slightly compressed, } \\
\text { broadly elliticicalt } \\
\text { narrowly oval, } 7.5-10.5 \times \\
6.5 \times 5.5 \mathrm{~mm}\end{array}$ & ND & ND & Basal, spherical & $\begin{array}{l}\text { Single, located in the } \\
\text { upper part of the cell }\end{array}$ & ND & $\begin{array}{l}\text { Deeply bilobed at the } \\
\text { anterior end }\end{array}$ & ND & [31] \\
\hline T. ascus & $\begin{array}{l}\text { Pacific coast of North } \\
\text { America and Japan; small } \\
\text { tide pools }\end{array}$ & $\begin{array}{c}\text { Elliptical, } 19-30 \times 8-16 \\
\qquad \mathrm{~m}\end{array}$ & ND & ND & $\begin{array}{l}\text { Large, circular, located } \\
\text { near the center of the cell, } \\
\text { surrounded by } \\
\text { lens-shaped starch grains; } \\
\text { Tetraselmis }\end{array}$ & $\begin{array}{l}\text { Located in the anterior } \\
\text { third of the chloroplast, } \\
1.5 \text { to } 2.0 \mu \mathrm{m} \text { indiameter, } \\
\text { a single region composed } \\
\text { of two or three layers of } \\
\text { lipid granules }\end{array}$ & ND & Four lobes in the anterior & $\begin{array}{l}5, \text { surrounding the basal } \\
\text { body }\end{array}$ & [34] \\
\hline T. astigmatica & $\begin{array}{l}\text { Pacific coast of North } \\
\text { America; salt marsh }\end{array}$ & $\begin{array}{l}\text { Spherical, } 11-19 \times 7-16 \\
\mu \mathrm{m}\end{array}$ & $\mathrm{ND}$ & ND & $\begin{array}{l}\text { Large, located in the } \\
\text { posterior part of the cell } \\
\text { surrounded by } \\
\text { lens-shaped starch grains; } \\
\text { Tetrasalminis }\end{array}$ & Not present & ND & $\begin{array}{l}\text { Large, invaginated with } \\
\text { cytoplasmic canaliculi in } \\
\text { the posterior }\end{array}$ & $\begin{array}{l}4, \text { surrounding the basal } \\
\text { body }\end{array}$ & [34] \\
\hline T. carteriiformis & Scotland; rock pools & $\begin{array}{c}\text { Compressed, ovoid in } \\
\text { front view, } 12-14 \times 9-10 \\
\times 7-8 \mu \mathrm{m}\end{array}$ & ND & ND & $\begin{array}{l}\text { Large, basal, irregularly } \\
\text { rounded, with a starch } \\
\text { sheath }\end{array}$ & $\begin{array}{l}\text { Single, sub-median, in the } \\
\text { region of the pyrenoid }\end{array}$ & Central & $\begin{array}{l}\text { Narrowly four-lobed, in } \\
\text { the region of the pyrenoid }\end{array}$ & $\mathrm{ND}$ & [31] \\
\hline T. chuii & $\begin{array}{l}\text { Europe and North } \\
\text { America; tide pools and } \\
\text { estuaries }\end{array}$ & $\begin{array}{l}\text { Compressed, elliptical to } \\
\text { obovate, 12-16 } \times 7-10 \\
\mu \mathrm{m}\end{array}$ & ND & ND & $\begin{array}{l}\text { Small, irregular in shape, } \\
\text { located far from the } \\
\text { nucleus surrounded by } \\
\text { concave-convex starch } \\
\text { grains }\end{array}$ & $\begin{array}{l}\text { Conspicuous, asingle } \\
\text { region composed of two } \\
\text { layers of osmiophilic } \\
\text { granules, 1.3-2.5 him in } \\
\text { size, located usually in the } \\
\text { upper region of the } \\
\text { pyrenoid, but variable in } \\
\text { position }\end{array}$ & $\begin{array}{l}\text { At the anterior half of the } \\
\text { cell body }\end{array}$ & Finely lobed & $\begin{array}{l}\text { 2, around the flagellar } \\
\text { base }\end{array}$ & [35] \\
\hline T. contracta & UK; marine & $\begin{array}{l}\text { Compressed, broadly } \\
\text { elliptical, } 25 \times 17 \times 11 \\
\mu \mathrm{m}\end{array}$ & ND & $\mathrm{ND}$ & Oval, medium, basal & $\begin{array}{l}\text { Single, conspicuous, } \\
\text { central to anterior }\end{array}$ & ND & $\begin{array}{l}\text { Two large and two small } \\
\text { apical lobes }\end{array}$ & ND & [31] \\
\hline T. convolutae & Europe and Japan; marine & $\begin{array}{c}\text { Compressed, shape } \\
\text { variable, occasionally } \\
\text { curved, 8-13 } 8 \text { ×-10 } \\
4-6 \mu \mathrm{m}\end{array}$ & ND & ND & $\begin{array}{l}\text { Conspicuous, } 2-4 \mu \mathrm{m} \text {, in } \\
\text { the posterior, appearing } \\
\text { eccentric with } \\
\text { ring-shaped starch }\end{array}$ & $\begin{array}{l}\text { Exceptionally large, } 1-2.3 \\
\text { } m \text {, located in the } \\
\text { anterior third of the body, } \\
\text { a single region composed } \\
\text { of two layers of } \\
\text { osmiophilic granules }\end{array}$ & Central & $\begin{array}{l}\text { Four lobes extending } \\
\text { forward from just behind } \\
\text { the middle of the body }\end{array}$ & $\begin{array}{l}2-4 \text {, around the flagellar } \\
\text { base }\end{array}$ & [32] \\
\hline T. cordiformis & Freshwater & $\begin{array}{c}\text { Compressed, obovate, } \\
17-19 \times 13-16 \times 8-11 \mu \mathrm{m}\end{array}$ & $\mathrm{ND}$ & $\mathrm{ND}$ & $\begin{array}{l}\text { Large, located directly } \\
\text { beneath the nucleus } \\
\text { surrounded by } \\
\text { biconvex-shaped starch } \\
\text { grains; the matrix } \\
\text { penetrated from all } \\
\text { directions with canaliculi }\end{array}$ & $\begin{array}{l}\text { Located near the middle } \\
\text { of one of the broad sides, } \\
\text { but considerably variable } \\
\text { in position, approximately } \\
1.5 \mu \mathrm{m} \text { in diameter }\end{array}$ & $\mathrm{ND}$ & $\begin{array}{l}\text { Large, highly reticulate in } \\
\text { the posterior }\end{array}$ & $\begin{array}{l}2-4, \text { around the flagellar } \\
\text { base }\end{array}$ & {$[33,34]$} \\
\hline
\end{tabular}


Table 1. Cont.

\begin{tabular}{|c|c|c|c|c|c|c|c|c|c|c|}
\hline Species & $\begin{array}{l}\text { Location and Type of } \\
\text { Habitat }\end{array}$ & Cell Shape and Size & Regular Subunit Pattern & $\begin{array}{l}\text { Specific Scales on the } \\
\text { Cell Surface }\end{array}$ & $\begin{array}{l}\text { Pyrrenoid Matrix and } \\
\text { Subgenus }\end{array}$ & Eyespot (Stigma) & Nuclear Position & Chloroplast & Golgi Bodies & References \\
\hline T. gracilis & Europe; marine & $\begin{array}{l}\text { Compressed, broadly to } \\
\text { narrowly elliptical, } 8-9 \times 1 \\
5.5-7.5 \times 5-6.5 \mu \mathrm{m}\end{array}$ & ND & ND & $\begin{array}{l}\text { Large, spherical, } \\
\text { sub-basal, with a } \\
\text { U-shaped starch sheath }\end{array}$ & $\begin{array}{l}\text { Single, conspicuous, } \\
\text { situated in the anterior } \\
\text { half of the cell }\end{array}$ & ND & $\begin{array}{l}\text { Uniformly and markedly } \\
\text { rugose, axile }\end{array}$ & ND & [31] \\
\hline T. hazeni & $\begin{array}{l}\text { Europe: Spain, and USA; } \\
\text { marine }\end{array}$ & $\begin{array}{l}\text { Compressed, elliptical to } \\
\text { oval, } 13-17 \times 7-8 \times 4-5 \\
\mu \mathrm{m}\end{array}$ & ND & ND & $\begin{array}{l}\text { Basal, cup shaped, rather } \\
\text { large }\end{array}$ & $\begin{array}{l}\text { Small, single, situated in } \\
\text { the upper part of the } \\
\text { pyrenoid }\end{array}$ & ND & $\begin{array}{l}\text { Cup shaped, with } 4 \\
\text { anterior lobes but } \\
\text { non-posterior }\end{array}$ & ND & [31] \\
\hline T. helgolandica & Helgoland; marine & $\begin{array}{l}\text { Compressed, oval, } 21-24 \\
\times 14-15 \times 7-9 \mu \mathrm{m}\end{array}$ & ND & ND & $\begin{array}{l}\text { Conspicuous, spherical, } \\
\text { sub-central to sub-basal, } \\
\text { with large starch grains }\end{array}$ & $3-6$ & ND & $\begin{array}{l}\text { A shorter posterior lobe, } \\
\text { and two longitudinal } \\
\text { lateral lobes }\end{array}$ & $\mathrm{ND}$ & [31] \\
\hline T. impellucida & Puerto Rico; marine & $\begin{array}{c}\text { Slightly compressed, } \\
\text { shape varaiale, } 14-23 \times \\
8-17 \mu \mathrm{m}\end{array}$ & ND & ND & $\begin{array}{l}\text { Absence of a starch sheath } \\
\text { around the pyrenoid, } \\
\text { lying posterior to nucleus }\end{array}$ & $\begin{array}{c}\text { Conspicuous, composed } \\
\text { of two layers }\end{array}$ & $\begin{array}{l}\text { Located subapically } \\
\text { below the apical trough }\end{array}$ & $\begin{array}{l}\text { Cup shaped, covering the } \\
\text { peripheral region with a } \\
\text { slit from the cell apex to } \\
\text { the middle of the body }\end{array}$ & ND & [42] \\
\hline T. inconspicua & Europe; marine & 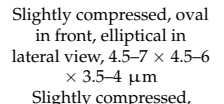 & ND & ND & $\begin{array}{c}\text { Basal, very small, } \\
\text { globular, with a } \\
\text { continuous starch sheath }\end{array}$ & $\begin{array}{l}\text { Single, conspicuous, in } \\
\text { the region of pyrenoid }\end{array}$ & ND & $\begin{array}{l}\text { Anterior two lobed to the } \\
\text { center of the cell }\end{array}$ & $\mathrm{ND}$ & [31] \\
\hline T. indica & $\begin{array}{l}\text { India (Goa); hypersaline } \\
\text { to marine }\end{array}$ & $\begin{array}{c}\text { Slightly compressed, } \\
\text { elliptical, and a folded } \\
\text { line faintly observed in } \\
\text { the broad lateral vivews; } \\
10-25 \times 7-20 \times 6.5-18 \\
\mu \mathrm{m}\end{array}$ & ND & $\begin{array}{l}\text { Observed, a hollow } \\
\text { rim-like shape }\end{array}$ & $\begin{array}{l}\text { Central, hardly observed } \\
\text { starch plates }\end{array}$ & $\begin{array}{l}\text { Conspicuous, one or } \\
\text { sometimes several, } \\
\text { situated below the } \\
\text { pyrenoid }\end{array}$ & $\begin{array}{l}\text { Present in the anterior } \\
\text { half of the cell }\end{array}$ & $\begin{array}{l}\text { Cup shaped with 4-8 } \\
\text { lobes }\end{array}$ & $\begin{array}{l}2-8, \text { around the flagellar } \\
\text { base }\end{array}$ & [41] \\
\hline T. levis & England; salt marsh & $\begin{array}{c}\text { Compressed, ovate, } 9-12 \\
\times 6-7.5 \mu \mathrm{m}\end{array}$ & $\mathrm{ND}$ & ND & $\begin{array}{l}\text { Irregular in shape, located } \\
\text { sub-centrally, surrounded } \\
\text { by biconvex starch grains; } \\
\text { Parviselmis }\end{array}$ & $\begin{array}{l}\text { Not conspicuous, located } \\
\text { in the region of the } \\
\text { pyrenoid }\end{array}$ & Near the flagellar base & $\begin{array}{l}\text { Finely lobed in the } \\
\text { posterior end }\end{array}$ & 2 & [35] \\
\hline T. maculata & $\begin{array}{l}\text { Europe, collected from } \\
\text { salt marsh pools and } \\
\text { apparently not common; } \\
\text { marine }\end{array}$ & $\begin{array}{l}\text { Slightly compressed, } \\
\text { ovate in front, elliptical in } \\
\text { lateral view, }-9.9 \times 5.5-7.7 \\
\times 5-6.5 \mu \mathrm{m}\end{array}$ & ND & ND & $\begin{array}{l}\text { Basal, medium, or small, } \\
\text { with a discontinuous } \\
\text { starch sheath }\end{array}$ & $\begin{array}{l}\text { Single, conspicuous, close } \\
\text { to the pyrenoid }\end{array}$ & ND & $\begin{array}{l}\text { Finely granular, anterior } \\
\text { two lobes }\end{array}$ & ND & [31] \\
\hline T. marina & $\begin{array}{l}\text { Europe, North America } \\
\text { and Japan; marine }\end{array}$ & $\begin{array}{l}\text { Plants unicellular or } \\
\text { colonial with a septate } \\
\text { stalk, cells elliptical, } 16-20 \\
\times 7-8 \mu \mathrm{m}\end{array}$ & ND & ND & $\begin{array}{l}\text { Large, almost spherical, } \\
\text { with concave starch grains }\end{array}$ & $\begin{array}{l}\text { Conspicuous, a single } \\
\text { region composed of two } \\
\text { layers, located twe } \\
\text { peripherally at a level } \\
\text { between the nucleus and } \\
\text { pyrenoid }\end{array}$ & ND & $\begin{array}{l}\text { Massive, cup shaped, } \\
\text { located peripherally with } \\
4 \text { anterior lobes }\end{array}$ & $\begin{array}{l}5, \text { near the anterior end of } \\
\text { the nucleus }\end{array}$ & [22] \\
\hline T. rubens & Europe; marine & $\begin{array}{c}\text { Compressed, } 8-11 \times 5-8 \\
\times 4.5-5 \mu \mathrm{m}\end{array}$ & $\mathrm{ND}$ & $\mathrm{ND}$ & $\begin{array}{l}\text { Basal, medium, globular } \\
\text { with a U-shaped starch } \\
\text { sheath }\end{array}$ & $\begin{array}{l}\text { Single, conspicuous, in } \\
\text { the anterior to the middle }\end{array}$ & $\mathrm{ND}$ & Anterior deeply 2 lobed & $\mathrm{ND}$ & [31] \\
\hline T. striata & $\begin{array}{l}\text { Europe and Japan; } \\
\text { brackish water and tide } \\
\text { pools }\end{array}$ & $\begin{array}{l}\text { Compressed, elliptical, } \\
7-11 \times 5.5-7.2 \mu \mathrm{m}\end{array}$ & ND & ND & $\begin{array}{l}\text { Small, located sub-basally, } \\
\text { surrounded by biconvex } \\
\text { starch grains; Parvoselmis }\end{array}$ & $\begin{array}{l}\text { Conspicuous, a single } \\
\text { region composed of one } \\
\text { or two layers, larger than } \\
\text { the pyrenoid matrixi, 1.7.-3 } \\
\mu \text { in idameter, located } \\
\text { lateral to the pyrenoid in } \\
\text { the posterior half }\end{array}$ & Central & $\begin{array}{l}\text { Dorsiventrally lobed into } \\
\text { two posterior sections }\end{array}$ & 2 & [35] \\
\hline T. subcordiformis & Norway; marine & $\begin{array}{l}\text { Compressed, elliptical, } \\
11-17 \times 8-10 \mu \mathrm{m}\end{array}$ & ND & ND & $\begin{array}{l}\text { Large, spherical, } \\
\text { sub-central to sub-basal } \\
\text { Spheroidal, locateded near }\end{array}$ & $\begin{array}{l}\text { Single, in lower part of } \\
\text { the cell near the pyrenoid }\end{array}$ & ND & $\begin{array}{l}\text { A shorter posterior lobe } \\
\text { and two lateral lobes }\end{array}$ & ND & [31] \\
\hline T. suecica & Brackish, marine & $\begin{array}{l}\text { Compressed, elliptical to } \\
\text { obovate, } 6-11 \times 4-8.5 \mu \mathrm{m}\end{array}$ & ND & ND & $\begin{array}{l}\text { Spheroidal, located near } \\
\text { the base, } 4 \text { urrounded by } \\
\text { concave-convex shapeded } \\
\text { starch grains; Parviselmis }\end{array}$ & $\begin{array}{l}\text { Not conspicuous, located } \\
\text { near the pyrenoid }\end{array}$ & Central & $\begin{array}{l}\text { Cup shaped, usually } \\
\text { simple, rarely biliobed in } \\
\text { the posterior part }\end{array}$ & 2 & [35] \\
\hline T. tetrathele & Europe; marine & $\begin{array}{l}\text { Compressed, elliptical, } \\
10-16 \times 8-11 \times 4.2-5 \mu \mathrm{m}\end{array}$ & ND & ND & $\begin{array}{l}\text { Large, spherical, } \\
\text { sub-central to sub-basal }\end{array}$ & $\begin{array}{l}\text { Single, sub-median, } \\
\text { usually situated in the } \\
\text { region of the eupper part } \\
\text { of the pyrenoid }\end{array}$ & $\mathrm{ND}$ & $\begin{array}{l}\text { Axile with a narrow sinus } \\
\text { reaching the pyrenoid, a } \\
\text { shorter posterior lobe and } \\
\text { two lateral lobes }\end{array}$ & $\mathrm{ND}$ & [31] \\
\hline T. verrucosa & $\begin{array}{l}\text { Europe and } \\
\text { Japan;;rackish water }\end{array}$ & $\begin{array}{l}\text { Compressed, elliptical in } \\
\text { front vivew with a deep } \\
\text { apical furrow in lateral } \\
\text { view, 8.5-10 } \times 6-6-5.5 \times \\
4.5-6 \mu \mathrm{m}\end{array}$ & ND & ND & $\begin{array}{l}\text { Small, spherical, } \\
\text { sub-basal or central, with } \\
\text { a starch sheath }\end{array}$ & $\begin{array}{l}\text { Single, conspicuous, and } \\
\text { variable in position }\end{array}$ & Scattered irregularly & $\begin{array}{l}\text { Massive, with } 2 \text { anterior } \\
\text { lobes near the pyrenoid } \\
\text { and } 4 \text { or more sublobes in } \\
\text { the anterior region, not } \\
\text { lobed posteriorly }\end{array}$ & $2-3$ & [31] \\
\hline
\end{tabular}


In [34], the authors proposed that the genus Teraselmis should be divided into four subgenera (Tetraselmis, Prasinocladia, Tetrathele, and Parviselmis) based on the ultrastructural features of the pyrenoid matrix, which is the ellipsoidal protein matrix that mediates efficient carbon fixation with the enzyme Rubisco, as visualized by TEM $[35,43,44]$. In Chile, several strains of Tetraselmis that were difficult to be distinguished as different species when using light microscopy, could be classified according to the criteria suggested by [34,45]. Two of them belonged to the subgenus Parviselmis, whereas the others belonged to the subgenus Tetrathele. By tracing these pyrenoid characteristics established as ultrastructural markers, we investigated the ultrastructures of T. jejuensis using TEM. The pyrenoid of the cell was surrounded by a starch sheath, wherein each starch granule was plate-shaped. The pyrenoid was invaded by several cytoplasmic channels in various directions with the presence of a major cavity that opened towards the nucleus, indicating that the species T. jejuensis belongs to the subgenus Tetrathele (Figure 5a,c and Figure 6). It is distinct from other Tetraselmis species belonging to the subgenera Tetraselmis (T. cordiformis, T. ascus, T. convolutae, T. astigmatic), Prasinocladia (T. marina, T. verrucosa, T. rubens), and Parviselmis (T. levis, T. chuii, T. suecica, T. alacris, T. striata) $[34,35,46]$.

Consistent with the above results, the ultrastructural features of $T$. jejuensis are different from those of other Tetraselmis species. First, the location of the pyrenoid matrix in the body of T. jejuensis is lower than that of other species, including T. alacris, T. ascus, T. chuii, T. indica, T. levis, and T. verrucosa $[31,34,35,41]$ (Figure 5a,c and Figure 6 and Table 1). Second, the eyespot (stigma) of Tetraselmis species is commonly apart from flagellar roots as a specific feature, whereas that in Chlamydomonas reinhardtii, with a well understood flagellar assembly, is located near the microtubule roots [33,47,48]. In TEM micrographs of T. jejuensis, numerous eyespot globules were observed in the lower part of the cell body, especially near the antapical base (Figure $5 \mathrm{a}, \mathrm{c})$. By light microscopy, numerous orange-red eyespot regions were found to be dispersed throughout the chloroplasts of $T$. jejuensis cells (Figure 1d-g). Notably, the number of eyespots in the T. jejuensis cell body was much higher than that previously reported in all other Tetraselmis species (Table 1). Most Tetraselmis species contain a single conspicuous eyespot region composed of one or two layers of osmiophilic granules in the cells [22,31-35]. Moreover, the eyespots of some species, such as T. alacris, T. astigmatica, T. levis, and T. suecica, were not present or were not conspicuous inside the protoplasm. Recently, Arora et al. [41] confirmed that Tetraselmis indica cells contain one or several eyespots below the pyrenoid. However, the number of eyespot globules in T. indica was far less than that in T. jejuensis. Melkonian \& Robenek discussed the possible role of the eyespot in Tetraselmis phototaxis as well as structural features that may indicate its importance to cell orientation toward light [49]. Since T. jejuensis was found in a shallow tidal pool that was affected by direct sunlight, it is thought that strong light influences the development of the eyespot. Thus, these distinctive features in the ultrastructure of $T$. jejuensis can play an important role in determining whether unidentified species could be T. jejuensis. The ultrastructural profile of T. jejuensis with the major cellular organelles is schematized in Figure 10. 


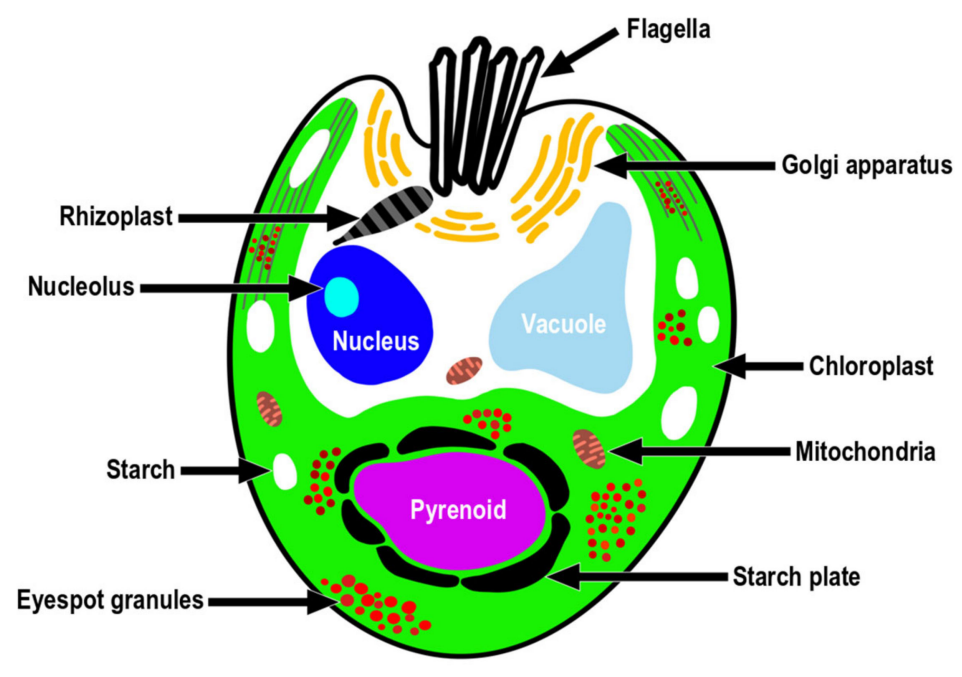

Figure 10. A schematic drawing of the ultrastructure indicating the position of the major cell organelles in Tetraselmis jejuensis.

Further investigation of the similarity between these cells and three Chilean strains of Tetraselmis reported by Gonzalez et al. [45] revealed that the ultrastructural arrangement of $T$. jejuensis is similar to that of the Dichato strain, despite the structures of the pyrenoid matrix differing. Although the environmental data for Coliumo Bay, where Dichato is located, was not provided at the time, we confirmed that the salinity of Coliumo Bay was approximately $1.36 \%$, measured at depths ranging from $2 \mathrm{~m}$ to $5 \mathrm{~m}$ in November 1996 [50]. The finding that these cells proliferate vigorously at salt concentrations lower than $2.0 \%$ corresponds to the physiological characteristic of T. jejuensis surviving in extreme salt concentrations ranging from $0.3 \%$ to $1.6 \%$ (Table 3). Unfortunately, comparison of aligned sequences between these strains is limited by the absence of deposited SSU rDNA sequences of the Chilean strains in GenBank [45].

The flagellar root system of Tetraselmis species has been well studied and established in previous studies $[22,33-35,41]$. It has been reported that Golgi bodies are commonly located around the flagellar base in Tetraselmis species because they are associated with flagellar regeneration via their activation [51,52]. The Golgi apparatus of T. jejuensis was found to be present around the basal complex surrounding them (Figure 7e-g). Furthermore, the structures of flagellar apparatus in the cells, including rhizoplasts, basal bodies, halfdesmosomes, and flagella pit hairs on the apical floor are equivalent to those of other Tetraselmis species, as reported previously.

To clarify the phylogenetic relationships between a newly branched clade containing T. jejuensis and other clades classified within the genus Tetraselmis, we compared the SSU rDNA sequences of 16 isolated T. jejuensis strains with those of the identified species in each clade, based on the number of base pairs that were different from each other. Four strains isolated from Daejeong (DJ) displayed 1.53\% similarity to T. suecica (MK541745), with $1.59 \%, 1.78 \%, 1.85 \%$, and $2.28 \%$ dissimilarity to T. chuii (DQ207405), T. subcordiformis (FJ559380), T. carteriiformis (FJ559384), and T. convolutae (U05039) as indicated for maximum value, respectively, indicating that the $T$. jejuensis DJ strains within the newly branched clade were $1.53 \%$ different from T. suecica (MK541745), which is the closest species in the Chlorodendrophyceae, based on the phylogenetic tree of SSU rDNA (Table 2). Next, we confirmed that 12 strains isolated from YO showed $1.19 \%$ dissimilarity to T. suecica (MK541745), with $1.39 \%, 1.55 \%, 1.61 \%$, and $2.11 \%$ dissimilarity to T. chuii (DQ207405), T. subcordiformis (FJ559380), T. carteriiformis (FJ559384), and T. convolutae (U05039) as indicated for the maximum value, respectively. Exceptionally, a strain (YO 2) found at a salinity of $3.9 \%$ showed $0.13 \%$ dissimilarity to T. subcordiformis, with $0.19 \%, 1.26 \%, 1.32 \%$, and $1.75 \%$ similarity to T. carteriiformis, T. suecica, T. chuii, and T. convolutae, respectively. These 
results indicated that T. jejuensis YO strains were 1.19\% different from T. suecica (MK541745), which is the closest species in the phylogenetic analysis, except for the YO 2 strain, which is analogous to T. subcordinormis (Table 2). Hence, a distinctive clade containing the DJ and YO strains within the Chlorodendrophyceae is considered a new species, based on the phylogenetic tree of SSU rDNA sequences.

Table 2. Comparison of SSU rDNA sequences between the isolated strains of Tetraselmis jejuensis and other Tetraselmis species, such as T. carteriiformis, T. subcordiformis, T. chuii, T. suecica, and T. convolutae. The numbers indicate different mismatched base pairs (bp) from each other. The numbers in parentheses indicate dissimilarity (\%) including gaps. The bold numbers represent the highest similarity among them.

\begin{tabular}{|c|c|c|c|c|c|}
\hline $\begin{array}{l}\text { Accession } \\
\text { Number }\end{array}$ & FJ559384 & FJ559380 & DQ207405 & MK541745 & U05039 \\
\hline Species & T. carteriiformis & T. subcordiformis & T. chuii & T. suecica & T. convolutae \\
\hline $\begin{array}{c}\text { Tetraselmis sp. DJ } \\
2-1\end{array}$ & $22(1.38)$ & $21(1.31)$ & $18(1.11)$ & 17 (1.05) & $29(1.79)$ \\
\hline $\begin{array}{l}\text { Tetraselmis sp. DJ } \\
2-4\end{array}$ & $23(1.48)$ & $22(1.41)$ & $20(1.28)$ & $19(1.22)$ & $31(1.98)$ \\
\hline $\begin{array}{c}\text { Tetraselmis sp. DJ } \\
2-5\end{array}$ & $24(1.50)$ & $23(1.44)$ & $20(1.25)$ & $19(1.19)$ & $31(1.93)$ \\
\hline $\begin{array}{c}\text { Tetraselmis sp. DJ } \\
2-2\end{array}$ & $29(1.85)$ & $28(1.78)$ & $25(1.59)$ & $24(1.53)$ & $36(2.28)$ \\
\hline $\begin{array}{c}\text { Tetraselmis sp. YO } \\
3-4\end{array}$ & $22(1.43)$ & $21(1.36)$ & $18(1.17)$ & $17(1.10)$ & $29(1.87)$ \\
\hline $\begin{array}{c}\text { Tetraselmis sp. YO } \\
3-3\end{array}$ & $25(1.56)$ & $24(1.50)$ & $21(1.31)$ & $18(1.13)$ & 32 (1.99) \\
\hline $\begin{array}{c}\text { Tetraselmis sp. YO } \\
3-5\end{array}$ & $25(1.53)$ & $24(1.47)$ & $22(1.32)$ & $17(1.06)$ & $34(2.03)$ \\
\hline $\begin{array}{l}\text { Tetraselmis sp. } \mathrm{YO} \\
3-2\end{array}$ & $25(1.53)$ & $24(1.47)$ & $21(1.27)$ & 17 (1.05) & $33(1.98)$ \\
\hline $\begin{array}{c}\text { Tetraselmis sp. YO } \\
3-1\end{array}$ & $25(1.53)$ & $24(1.47)$ & $18(1.07)$ & 17 (1.05) & $33(1.96)$ \\
\hline $\begin{array}{c}\text { Tetraselmis sp. YO } \\
4-1\end{array}$ & $22(1.36)$ & $21(1.30)$ & $18(1.10)$ & 17 (1.04) & 29 (1.77) \\
\hline $\begin{array}{c}\text { Tetraselmis sp. YO } \\
4-2\end{array}$ & $22(1.36)$ & $21(1.30)$ & $18(1.11)$ & $17(1.05)$ & $29(1.79)$ \\
\hline $\begin{array}{c}\text { Tetraselmis sp. YO } \\
5-5\end{array}$ & $24(1.48)$ & $23(1.42)$ & $23(1.39)$ & 17 (1.06) & $35(2.11)$ \\
\hline $\begin{array}{l}\text { Tetraselmis sp. YO } \\
3-11\end{array}$ & $10(0.98)$ & $9(0.88)$ & $9(0.88)$ & $6(0.60)$ & $13(1.27)$ \\
\hline $\begin{array}{c}\text { Tetraselmis sp. YO } \\
3-12\end{array}$ & $26(1.61)$ & $25(1.55)$ & $22(1.37)$ & 19 (1.19) & $33(2.04)$ \\
\hline $\begin{array}{c}\text { Tetraselmis sp. YO } \\
3-14\end{array}$ & $13(1.22)$ & $12(1.13)$ & $15(1.39)$ & $11(1.06)$ & $19(1.76)$ \\
\hline Tetraselmis sp. YO 2 & $3(0.19)$ & $2(0.13)$ & $21(1.32)$ & $20(1.26)$ & $28(1.75)$ \\
\hline
\end{tabular}

Consistent with the phylogenetic analysis, the ultrastructural details of T. jejuensis were different from those of T. suecica, its closest species. T. jejuensis cells had numerous eyespot globules and belonged to the subgenus Tetrathele, whereas T. suecica cells were characterized by non-conspicuous eyespots and belonged to the subgenus Parviselmis. Moreover, according to Fabregas et al. [53], the optimal salinity for growth in T. suecica was between $2.5 \%$ and 3.5\%; Pugkaew et al. [39] also confirmed that the optimal salinity range of T. suecica for growth was $2.0 \%-6.0 \%$, whereas significant growth inhibition was observed at a low salt concentration (1.0\%). However, T. jejuensis DJ and YO strains isolated from supralittoral tide pools on Jeju Island actively thrive and grow in their habitats with salinities of $0.3 \%, 0.5 \%, 0.8 \%, 1.6 \%$, and $3.1 \%$, respectively (Table 3). Given the differences based on phylogenetic, ultrastructural, and physiological features, $\mathrm{T}$. jejuensis is distinct from T. suecica. 


\section{Materials and Methods \\ 4.1. Sample Collection and Strain Setup}

Microalgal samples containing Tetraselmis species were collected from two supralittoral tide pools, Daejeong $(33.2126,126.2948)$ and Yongduam $(33.5159,126.5120)$, on Jeju Island in April and June 2019 (Figure 11, Table 3). For getting samples with various salinity concentrations from $0 \%$ to $4 \%$, sampling was performed 5 days after rainfall. The salt concentrations of samples from Daejeong (DJ), located in the south of Jeju, varied from $0.5 \%$ to $2.6 \%$, and those from Yongduam (YO) in North Jeju ranged from $0.3 \%$ to $4.4 \%$, because the salinities of these tide depressions were different at the time of sampling. The average temperatures of DJ and $\mathrm{YO}$ at the sampling time were $21.3^{\circ} \mathrm{C}$ and $25.1^{\circ} \mathrm{C}$, respectively. Live samples were transferred to the laboratory, and single cells were isolated in six-well plates using a dissecting microscope (SZX10, Olympus, Tokyo, Japan). Clonal cultures of T. jejuensis were established using two serial single-cell isolations. Cells were grown in $\mathrm{f} / 2$ culture medium [54] at $22{ }^{\circ} \mathrm{C}$, with continuous illumination at $65 \mu \mathrm{mol}$ photons $/ \mathrm{m}^{2} / \mathrm{s}$, and optimal salinities of $0.3,0.5,0.8,1.6,3.1$, and $3.9 \%$ based on the salt concentrations of each collected sample (Table 3). After sufficient growth, the clonal cultures were transferred to $30 \mathrm{~mL}$ flasks and $200 \mathrm{~mL}$ PC bottles. Sixteen strains of T. jejuensis (4 strains from DJ, and 12 strains from $Y O)$ were established, up to a cell density of at least $5.0 \times 10^{4}$ cells $/ \mathrm{mL}$.
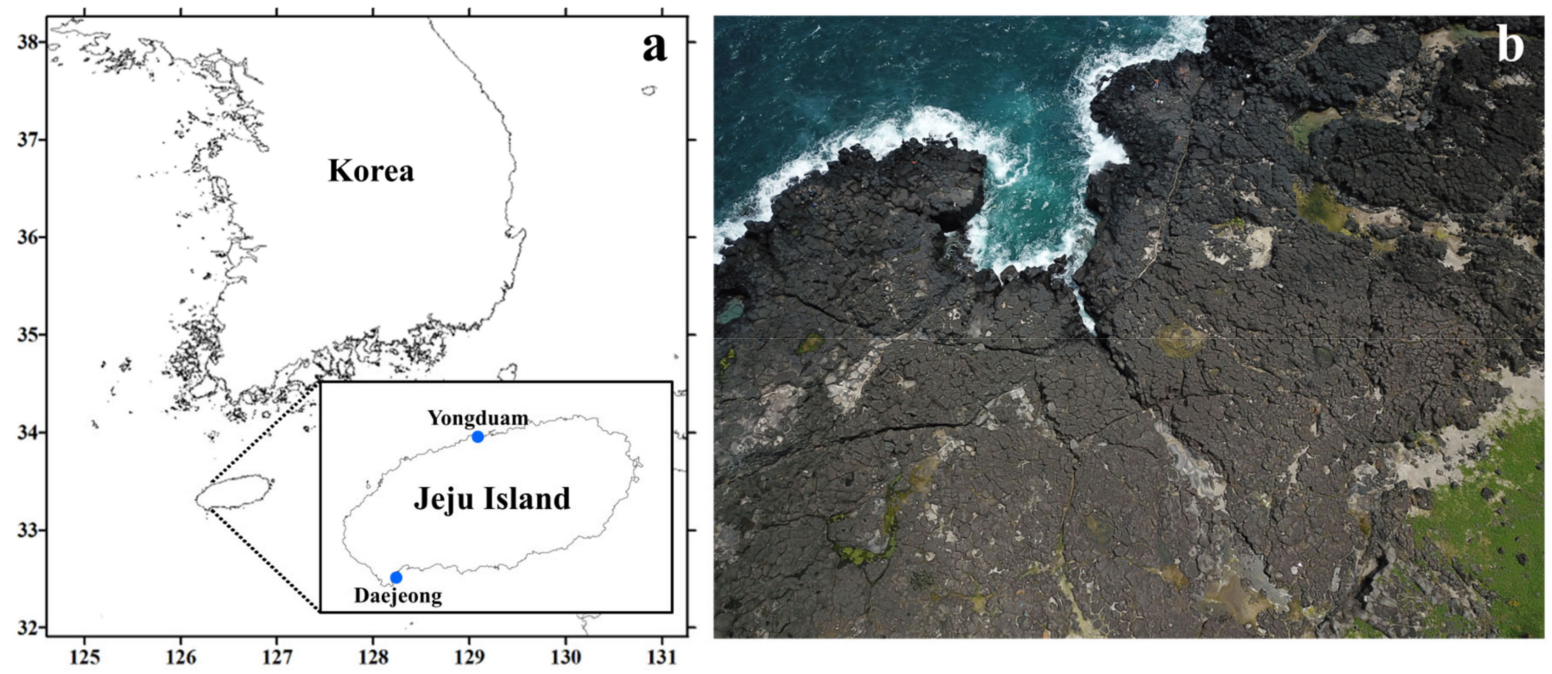

Figure 11. Location and aerial photographs of the sampling sites in Jeju Island. (a) Map of the sampling sites; location of Daejeong and Yongduam sites in Jeju Island. (b) The images show supralittoral tide pools made of basalt on the coastline of Jeju Island, Korea; images acquired using an unmanned aerial vehicle (UAV). 
Table 3. Collection details of Tetraselmis jejuensis isolated from two supralittoral tide pools, Daejeong (DJ) and Yongduam (YO), at Jeju Island in April and June 2019. The salinity and temperature measured at the time are indicated along with the date and location.

\begin{tabular}{|c|c|c|c|c|c|c|}
\hline Strains & $\begin{array}{l}\text { Sampling } \\
\text { Date }\end{array}$ & $\begin{array}{c}\text { Salinity } \\
(\%)\end{array}$ & $\begin{array}{c}\text { Temperature } \\
\left({ }^{\circ} \mathrm{C}\right)\end{array}$ & Location & Latitude & Longitude \\
\hline $\begin{array}{l}\text { Tetraselmis } \\
\text { sp. DJ 2-1 }\end{array}$ & \multirow{9}{*}{$\begin{array}{l}11 \mathrm{Apr} \\
2019\end{array}$} & 0.5 & 19.0 & Daejeong & 33.2126 & 126.2948 \\
\hline $\begin{array}{l}\text { Tetraselmis } \\
\text { sp. DJ 2-4 }\end{array}$ & & 0.5 & 19.0 & Daejeong & 33.2126 & 126.2948 \\
\hline $\begin{array}{l}\text { Tetraselmis } \\
\text { sp. DJ 2-5 }\end{array}$ & & 0.5 & 19.0 & Daejeong & 33.2126 & 126.2948 \\
\hline $\begin{array}{l}\text { Tetraselmis } \\
\text { sp. DJ 2-2 }\end{array}$ & & 0.5 & 19.0 & Daejeong & 33.2126 & 126.2948 \\
\hline $\begin{array}{l}\text { Tetraselmis } \\
\text { sp. YO 3-4 }\end{array}$ & & 0.3 & 20.8 & Yongduam & 33.5159 & 126.5120 \\
\hline $\begin{array}{l}\text { Tetraselmis } \\
\text { sp. YO 3-3 }\end{array}$ & & 0.3 & 20.8 & Yongduam & 33.5159 & 126.5120 \\
\hline $\begin{array}{l}\text { Tetraselmis } \\
\text { sp. YO 3-5 }\end{array}$ & & 0.3 & 20.8 & Yongduam & 33.5159 & 126.5120 \\
\hline $\begin{array}{l}\text { Tetraselmis } \\
\text { sp. YO 3-2 }\end{array}$ & & 0.3 & 20.8 & Yongduam & 33.5159 & 126.5120 \\
\hline $\begin{array}{l}\text { Tetraselmis } \\
\text { sp. YO 3-1 }\end{array}$ & & 0.3 & 20.8 & Yongduam & 33.5159 & 126.5120 \\
\hline $\begin{array}{l}\text { Tetraselmis } \\
\text { sp. YO 4-1 }\end{array}$ & \multirow{7}{*}{16 Jun 2019} & 0.8 & 29.9 & Yongduam & 33.5159 & 126.5120 \\
\hline $\begin{array}{l}\text { Tetraselmis } \\
\text { sp. YO 4-2 }\end{array}$ & & 0.8 & 29.9 & Yongduam & 33.5159 & 126.5120 \\
\hline $\begin{array}{l}\text { Tetraselmis } \\
\text { sp. YO 5-5 }\end{array}$ & & 1.6 & 30.4 & Yongduam & 33.5159 & 126.5120 \\
\hline $\begin{array}{c}\text { Tetraselmis } \\
\text { sp. YO } \\
3-11\end{array}$ & & 3.1 & 29.4 & Yongduam & 33.5159 & 126.5120 \\
\hline $\begin{array}{c}\text { Tetraselmis } \\
\text { sp. YO } \\
3-12\end{array}$ & & 3.1 & 29.4 & Yongduam & 33.5159 & 126.5120 \\
\hline $\begin{array}{c}\text { Tetraselmis } \\
\text { sp. YO } \\
3-14\end{array}$ & & 3.1 & 29.4 & Yongduam & 33.5159 & 126.5120 \\
\hline $\begin{array}{l}\text { Tetraselmis } \\
\text { sp. YO } 2\end{array}$ & & 3.9 & 29.5 & Yongduam & 33.5159 & 126.5120 \\
\hline
\end{tabular}

\subsection{Microscopy}

Living cells were observed under a light microscope, and their length and width were measured using an Olympus BX 53 microscope equipped with a DP73 digital camera system (Olympus, Tokyo, Japan). For field emission scanning electron microscopy (FESEM: Sigma 500/VP, Carl Zeiss, Oberkochen, Germany), $10 \mathrm{~mL}$ aliquots of cultures at approximately $2 \times 10^{6}$ cells $\mathrm{mL}^{-1}$ were fixed for $10 \mathrm{~min}$ in osmium tetroxide $\left(\mathrm{OsO}_{4}\right.$, Electron Microscopy Sciences, Hatfield, PA, USA) at a final concentration of $1 \%(v / v)$. The fixed cells were collected on $3 \mu \mathrm{m}$ pore size polycarbonate membrane filters (Whatman, Kent, UK) and washed thrice with 50\% filtered seawater diluted with distilled water to remove residual salts. The membranes with attached cells were dehydrated in an ethanol series $(10,30,50,70,90$, and $100 \%$ ethanol, followed by two changes in $100 \%$ ethanol (Merck, Darmstadt, Germany), and were immediately dried using an automated critical point dryer (EM CPD300, Leica, Wetzlar, Germany). The dried filters were mounted on an aluminum stub (Electron Microscopy Sciences, Hatfield, PA, USA) using copper conductive double-sided tape (Ted Pella, Redding, CA, USA), and coated with gold using an ion sputter 
(MC1000, Hitachi, Tokyo, Japan). The cells and surface morphologies were observed using a high resolution Zeiss Sigma 500 VP field-emission scanning electron microscope (FE-SEM, Sigma 500/VP, Carl Zeiss, Oberkochen, Germany). The apical depression width, width of specific scales, regular subunit patterns on the cell surface, and thin pit hair length of T. jejuensis cells were measured using SEM micrographs (SmartSEM version 6.08, Carl Zeiss, Oberkochen, Germany). For transmission electron microscopy (TEM), cells were transferred to a $10 \mathrm{~mL}$ tube and fixed in $2.5 \%(v / v)$ glutaraldehyde (final concentration) for $1.5 \mathrm{~h}$. Tube contents were placed in a $10 \mathrm{~mL}$ centrifuge tube and concentrated at $1610 \times \mathrm{g}$ for $10 \mathrm{~min}$ in a Vision Centrifuge VS-5500 (Vision, Bucheon, Korea). The resulting pellet was subsequently transferred to a $1.5 \mathrm{~mL}$ tube and rinsed in $0.2 \mathrm{M}$ sodium cacodylate buffer (Electron Microscopy Sciences, Hatfield, PA, USA) at pH 7.4. After several rinses in $0.2 \mathrm{M}$ sodium cacodylate buffer, cells were post-fixed for $90 \mathrm{~min}$ in $1 \%(w / v) \mathrm{OsO}_{4}$ in deionized $\mathrm{H}_{2} \mathrm{O}$. The pellet was then embedded in agar. Dehydration was performed in a graded ethanol series $(50,60,70,80,90$, and $100 \%$ ethanol, followed by two changes in 100\% ethanol). The material was embedded in Spurr's resin (Electron Microscopy Sciences, Hatfield, PA, USA). Sections were prepared using an EM UC7 ultramicrotome (Leica, Wetzlar, Germany) and stained with 3\% (w/v) aqueous uranyl acetate (Electron Microscopy Sciences, Hatfield, PA, USA) followed by lead citrate (Electron Microscopy Sciences, Hatfield, PA, USA). The sections were visualized using Sigma 500/VP TEM (Sigma 500/VP, Carl Zeiss, Oberkochen, Germany). The length and width of the pyrenoid and the slit width of the embedded basal bodies of T. jejuensis cells were measured using TEM micrographs (SmartSEM version 6.08, Carl Zeiss, Oberkochen, Germany).

\subsection{DNA Extraction and PCR Amplification}

We prepared $2 \mathrm{~mL}$ of Tetraselmis jejuensis cultures with a density of $1.0 \times 10^{5}$ cells $/ \mathrm{mL}$, collected cell pellets by centrifugation at $19,745 \times g$ for $3 \mathrm{~min}$, and stored these at $-80^{\circ} \mathrm{C}$ until DNA extraction. In brief, we extracted total genomic DNA (gDNA) from the preserved pellets using the AccuPrep Genomic DNA Extraction Kit (BIONEER, Daejeon, Korea), following the manufacturer's instructions. The rDNA was then amplified using universal eukaryotic primers [55-59]. The reaction mixtures for PCR amplification contained $5 \mu \mathrm{L}$ of 10X F-Star Taq Reaction Buffer with $1 \mu \mathrm{L}$ of $10 \mathrm{mM}$ dNTP mix, $0.02 \mu \mathrm{M}$ of primers, $0.25 \mu \mathrm{L}$ of $5 \mathrm{U} / \mu \mathrm{L}$ BioFACT ${ }^{\mathrm{TM}}$ F-Star Taq DNA polymerase (BioFACT Co., Ltd., Daejeon, Korea), $38.75 \mu \mathrm{L}$ of UltraPure ${ }^{\mathrm{TM}}$ DNAse/RNAse-Free Distilled Water (Invitrogen, Carlsbad, CA, USA), and $3 \mu \mathrm{L}$ of DNA template (ca. 10-30 ng of DNA concentration). PCR amplification was conducted using an Eppendorf Mastercycler PCR machine (Eppendorf, Hamburg, Germany) under the following thermal cycling conditions: pre-denaturation at $94{ }^{\circ} \mathrm{C}$ for $5 \mathrm{~min}$, followed by 40 cycles of $95^{\circ} \mathrm{C}$ for $30 \mathrm{~s}$, the selected annealing temperature (AT) for $30 \mathrm{~s}, 72{ }^{\circ} \mathrm{C}$ for $1 \mathrm{~min}$, and a final extension at $72{ }^{\circ} \mathrm{C}$ for $10 \mathrm{~min}$. The AT of the primers was determined using gradient PCR. We optimized the AT as follows: $56.0^{\circ} \mathrm{C}$ (EukA-G18R), $56.0^{\circ} \mathrm{C}$ (570F-EukB), $60.0{ }^{\circ} \mathrm{C}$ (EukA-EukB), 58.0 ${ }^{\circ} \mathrm{C}$ (ITSF2-LSUB), $56.0^{\circ} \mathrm{C}$ (ITSF2-LSU500R), and $56.0^{\circ} \mathrm{C}$ (Euk1209F-1483R). Sequences of the universal primers were specified in Table 4. PCR products were purified using AccuPrep PCR Purification Kit (BIONEER, Daejeon, Korea) and subjected to Sanger sequencing provided by BIONEER service, and the obtained nucleotide sequences were identified using BLAST in the National Center for Biotechnology Information (NCBI) database. 
Table 4. Universal eukaryotic primers used to amplify the SSU, ITS, and LSU regions of ribosomal DNA.

\begin{tabular}{cllc}
\hline Primer Name & Primer Region & Sequence (5'-3') & Reference \\
\hline EukA & Forward, SSU & AACCTGGTTGATCCTGCCAG & {$[55]$} \\
G18R & Reverse, SSU & GCATCACAGACCTGTTATTG & {$[56]$} \\
570F & Forward, SSU & GTAATTCCAGCTCCAATAGC & {$[57]$} \\
EukB & Reverse, SSU & TGATCCTTCTGCAGGTTCACCTAC & {$[55]$} \\
ITSF2 & Forward, ITS & TACGTCCCTGCCCTTTGTAC & {$[56]$} \\
LSUB & Reverse, LSU & ACGAACGATTTGCACGTCAG & {$[56]$} \\
LSU500R & Reverse, LSU & CCCTCATGCTACTTGTTTGC & {$[56]$} \\
LSU500F & Foward, LSU & GCAAACAAGTACCATGAGGG & {$[56]$} \\
Euk1209F & Forward, ITS & GGGCATCACAGACCTG & {$[58]$} \\
ITSFR2 & Reverse, ITS & TCCCTGTTCATTCGCCATTAC & {$[56]$} \\
1483R & Reverse, LSU & GCAAACAAGTACCATGAGGG & {$[59]$} \\
\hline
\end{tabular}

\subsection{Phylogenetic Analysis}

The test species based on similarities in phylogenetic analysis were obtained from GenBank and related studies [13,41]. Seventy SSU rDNA sequences from the class Chlorodendrophyceae were included, which contained 16 isolated strains of Tetraselmis species from this study and 51 relatives, as well as Trebouxiaceae, from which three species were used as outgroups. These sequences were aligned using the SILVA alignment service [60]. A phylogenetic tree of aligned sequences was constructed using the maximum likelihood (ML) algorithm in MEGA7 [61]. ML bootstrap values were calculated using 1000 replicates from the same substitution model.

\section{Conclusions}

We found euryhaline microalga, Tetraselmis jejuensis, adapted to supralittoral tide pools on Jeju Island, Korea, in which salinities ranged from $0.3 \%$ to $3.1 \%$. For taxonomic identification, isolated strains from DJ and YO were examined by light microscopy, SEM, TEM, and phylogenetic analysis based on SSU rDNA sequences. First, the cells have specific scales and a regular subunit pattern, with a honeycomb-like structure, on the cell surface. Second, the pyrenoid structures of the cells belong to the subgenus Tetrathele, whereas those of most other Tetraselmis are included in the subgenera Tetraselmis, Prasinocladia, and Parviselmis. Notably, a large number of eyespot globules are dispersed throughout the chloroplast, especially at the posterior part of the cell body. For phylogenetic relationships, both DJ and YO strains constitute a newly branched clade in Chlorodendrophyceae based on SSU rDNA sequences. Each of the strains shows $1.53 \%$ and $1.19 \%$ dissimilarity with T. suecica, the closest species, respectively. Fifteen strains, including the separate clade, were regarded as the same species. The physiological features of these strains surviving under natural salinity conditions ranging from $0.3 \%$ to $3.1 \%$ are distinct compared to those of the other Tetraselmis species. To our knowledge this is the first report of Tetraselmis species living in supralittoral tide pools on Jeju Island, Korea. These results led us to propose the isolated species showing optimal growth in salinities of $0.3 \%$ to $3.1 \%$ as Tetraselmis jejuensis.

\section{Taxonomic Summary}

Phylum Chlorophyta [62]

Class Chlorodendrophyceae [17]

Order Chlorodendrales [16]

Family Chlorodendraceae [63]

Tetraselmis jejuensis sp. nov.

Diagnosis: Cells are compressed and elliptical in shape. The anteroposterior (AP) length, width, and depth of the cells in the broad lateral view measured by light microscopy were 13.0-20.8 $\mu \mathrm{m}, 6.5-16.3 \mu \mathrm{m}$, and 9.8-13.0 $\mu \mathrm{m}$, respectively. The cells are covered by a scale-based theca with four equal flagella emerging from an apical depression in two 
opposite pairs. There are four distinct creases on the cell surface. Each deep-folded line on the broad or narrow lateral sides of the cell is carved in the middle of the cell body and extends longitudinally from the anterior to the posterior of the cells. Specific scales are spread over the cell surface, especially at the antapical side. In the broad lateral views of the cells, there is a unique, regular subunit pattern with honeycomb-like structures on the surface at the posterior part near the crease. The nucleus located in the upper part of the cell body is close to the flagellar apparatus. The yellow-green, cup-shaped chloroplast contains a pyrenoid and numerous eyespot globules. The pyrenoid is located in the lower part of the cell body adjacent to the basal position; the length and width of the pyrenoid in the longitudinal view are 1.3-4.0 $\mu \mathrm{m}(2.7 \pm 1.0 \mu \mathrm{m})$, and $2.0-5.2 \mu \mathrm{m}(3.6 \pm 1.0 \mu \mathrm{m})$, respectively, as measured by TEM. The pyrenoid matrix is invaded by a major cavity filled with cytoplasmic channels and several canaliculi in various directions, and is surrounded by starch in a plate shape. Numerous orange-red eyespot globules are mostly located in the lower part of the cell body, especially near the basal position, and are dispersed throughout the chloroplast. Two to four Golgi bodies encircle the basal complex around the flagellar base. The cells undergo asymmetric cell division, and the daughter cells show morphological and ultrastructural differences within clonal cells.

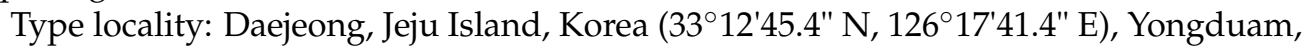
Jeju Island, Korea ( $\left.33^{\circ} 30^{\prime} 57.2^{\prime \prime} \mathrm{N}, 126^{\circ} 30^{\prime} 43.3^{\prime \prime} \mathrm{E}\right)$.

Etymology: The specific name "jejuensis" refers to the name of the collection site on Jeju Island, Korea.

\section{Holotype}

The SEM stub containing the type material from strain XXXXXX was deposited at the collection of the National Marine Biodiversity Institute of Korea (MABIK), Seocheon, South Korea, under accession number MABIKfl00030738. Gene sequence: DNA sequences obtained from clonal strains of Tetraselmis jejuensis were deposited in GenBank under accession no. MZ435987, MZ435988, MZ435989, MZ435990, MZ43591, MZ435992, MZ435993, MZ435994, MZ435995, MZ435996, MZ435997, MZ435998, MZ435999, MZ436000 and MZ436001.

Author Contributions: Conceptualization, experiment, data analyses, writing—original draft preparation, J.-H.H.; Culture collection, strain setup and culturing, E.-J.K.; methodology, microscopic analysis, S.-J.M.; morphological analysis with electron microscopy, writing-review and editing, N.S.K.; conceptualization, supervision, project administration, writing-review and editing, J.P. All authors have read and agreed to the published version of the manuscript.

Funding: This research was a part of the project titled "Improvement of management strategies on marine disturbing and harmful organisms (No. 20190518)" funded by the Ministry of Oceans and Fisheries, Korea, and supported by the National Research Foundation of Korea (NRF) grant funded by the Korea government (MSIT) (NRF-2018R1D1A1A02043893) and the National Marine Biodiversity Institute Research Program (MABIK no. 2021M00100).

Data Availability Statement: The data presented in this study are available on request from the corresponding authors. In addition, the data that support the findings of this study are openly available in GenBank with the accession numbers MZ435987, MZ435988, MZ435989, MZ435990, MZ43591, MZ435992, MZ435993, MZ435994, MZ435995, MZ435996, MZ435997, MZ435998, MZ435999, MZ436000 and MZ436001.

Acknowledgments: We thank J.H. Baek and S.W. Kim for their technical support.

Conflicts of Interest: The authors declare no conflict of interest.

\section{References}

1. Williams, P.J.L.B.; Laurens, L.M. Microalgae as biodiesel \& biomass feedstocks: Review \& analysis of the biochemistry, energetics \& economics. Energy Environ. Sci. 2010, 3, 554-590.

2. Da Silva Vaz, B.; Moreira, J.B.; de Morais, M.G.; Costa, J.A.V. Microalgae as a new source of bioactive compounds in food supplements. Curr. Opin. Food Sci. 2016, 7, 73-77. 
3. Martínez Andrade, K.A.; Lauritano, C.; Romano, G.; Ianora, A. Marine microalgae with anti-cancer properties. Mar. Drugs 2018, 16, 165. [CrossRef]

4. Borowitzka, M.A. Algal biotechnology products and processes-Matching science and economics. J. Appl. Phycol. 1992, 4, 267-279. [CrossRef]

5. Tredici, M.; Materassi, R. From open ponds to vertical alveolar panels: The Italian experience in the development of reactors for the mass cultivation of phototrophic microorganisms. J. Appl. Phycol. 1992, 4, 221-231. [CrossRef]

6. Pate, R.; Klise, G.; Wu, B. Resource demand implications for US algae biofuels production scale-up. Appl. Energy 2011, 88, 3377-3388. [CrossRef]

7. Isdepsky, A.; Borowitzka, M.A. In-pond strain selection of euryhaline Tetraselmis sp. strains for reliable long-term outdoor culture as potential sources of biofuel and other products. J. Appl. Phycol. 2019, 31, 3359-3370. [CrossRef]

8. Lee, Y.-K. Microalgal mass culture systems and methods: Their limitation and potential. J. Appl. Phycol. 2001, 13, 307-315. [CrossRef]

9. Bartley, M.L.; Boeing, W.J.; Corcoran, A.A.; Holguin, F.O.; Schaub, T. Effects of salinity on growth and lipid accumulation of biofuel microalga Nannochloropsis salina and invading organisms. Biomass Bioenergy 2013, 54, 83-88. [CrossRef]

10. Fon-Sing, S.; Borowitzka, M. Isolation and screening of euryhaline Tetraselmis spp. suitable for large-scale outdoor culture in hypersaline media for biofuels. J. Appl. Phycol. 2016, 28, 1-14. [CrossRef]

11. Montero, M.F.; Aristizábal, M.; Reina, G.G. Isolation of high-lipid content strains of the marine microalga Tetraselmis suecica for biodiesel production by flow cytometry and single-cell sorting. J. Appl. Phycol. 2011, 23, 1053-1057. [CrossRef]

12. Grierson, S.; Strezov, V.; Bray, S.; Mummacari, R.; Danh, L.T.; Foster, N. Assessment of bio-oil extraction from Tetraselmis chui microalgae comparing supercritical CO2, solvent extraction, and thermal processing. Energy Fuels 2012, 26, 248-255. [CrossRef]

13. Pereira, H.; Gangadhar, K.N.; Schulze, P.S.; Santos, T.; De Sousa, C.B.; Schueler, L.M.; Custódio, L.; Malcata, F.X.; Gouveia, L.; Varela, J.C. Isolation of a euryhaline microalgal strain, Tetraselmis sp. CTP4, as a robust feedstock for biodiesel production. Sci. Rep. 2016, 6, 35663. [CrossRef]

14. Kirst, G. Salinity tolerance of eukaryotic marine algae. Annu. Rev. Plant Biol. 1990, 41, 21-53. [CrossRef]

15. Guillou, L.; Eikrem, W.; Chrétiennot-Dinet, M.-J.; Le Gall, F.; Massana, R.; Romari, K.; Pedrós-Alió, C.; Vaulot, D. Diversity of picoplanktonic prasinophytes assessed by direct nuclear SSU rDNA sequencing of environmental samples and novel isolates retrieved from oceanic and coastal marine ecosystems. Protist 2004, 155, 193-214. [CrossRef]

16. Melkonian, M. Phylum chlorophyta class Prasinophyceae. In Handbook of Protoctista; Margulis, L., Corliss, J.O., Melkonian, M., Chapman, D.J., Eds.; Jones and Bartlett Publishers: Boston, MA, USA, 1990; pp. 600-607.

17. Massjuk, N. Chlorodendrophyceae class nov. (Chlorophyta, Viridiplantae) in the Ukrainian flora: I. The volume, phylogenetic relations and taxonomical status. Ukr. Bot. J. 2006, 63, 601-614.

18. Leliaert, F.; Smith, D.R.; Moreau, H.; Herron, M.D.; Verbruggen, H.; Delwiche, C.F.; De Clerck, O. Phylogeny and molecular evolution of the green algae. Crit. Rev. Plant Sci. 2012, 31, 1-46. [CrossRef]

19. Nakayama, T.; Marin, B.; Kranz, H.D.; Surek, B.; Huss, V.A.; Inouye, I.; Melkonian, M. The basal position of scaly green flagellates among the green algae (Chlorophyta) is revealed by analyses of nuclear-encoded SSU rRNA sequences. Protist 1998, 149, 367-380. [CrossRef]

20. Marin, B. Nested in the Chlorellales or independent class? Phylogeny and classification of the Pedinophyceae (Viridiplantae) revealed by molecular phylogenetic analyses of complete nuclear and plastid-encoded rRNA operons. Protist 2012, 163, 778-805. [CrossRef] [PubMed]

21. Turmel, M.; de Cambiaire, J.-C.; Otis, C.; Lemieux, C. Distinctive architecture of the chloroplast genome in the chlorodendrophycean green algae Scherffelia dubia and Tetraselmis sp. CCMP 881. PLoS ONE 2016, 11, e0148934. [CrossRef] [PubMed]

22. Norris, R.E.; Hori, T.; Chihara, M. Revision of the genus Tetraselmis (class Prasinophyceae). Bot. Mag. Shokubutsu Gaku Zasshi 1980, 93, 317-339. [CrossRef]

23. Mattox, K. Classification of the green algae: A concept based on comparative cytology. In Systematics of the Green Algae; Irvine, D.E.G., John, D.M., Eds.; Academic Press: London, UK, 1984; pp. $29-72$.

24. Garrity, S.D. Some adaptations of gastropods to physical stress on a tropical rocky shore. Ecology 1984, 65, 559-574. [CrossRef]

25. Ahmad, I.; Hellebust, J.A. Osmoregulation in the extremely euryhaline marine micro-alga Chlorella autotrophica. Plant Physiol. 1984, 74, 1010-1015. [CrossRef] [PubMed]

26. Kwun, H.J.; Park, J.; Kim, H.S.; Bae, H. Preliminary report on fish diversity in the tidal pools of Jeju Island, Korea. Mar. Biodivers. 2017, 47, 957-963. [CrossRef]

27. Blackwell, J.R.; Gilmour, D.J. Stress tolerance of the tidal pool chlorophyte, Chlorococcum submarinum. Br. Phycol. J. 1991, 26, 141-147. [CrossRef]

28. Lee, J.-B. Growth Charateristics of Five Microalgal Species Isolated from Jeju Island and Four Microalgal stock Strans in Hatchery. Algae 2002, 17, 117-125. [CrossRef]

29. Kylin, J.H. Über Rhodomonas, Platymonas und Prasinocladus. K. Fysiogr. Sällsk. Lund Förh 1935, 5, 1-13.

30. Proskauer, J. On Prasinocladus. Am. J. Bot. 1950, 37, 59-66. [CrossRef]

31. Butcher, R.W. An introductory account of the smaller algae of British coastal waters Part I. Introduction and Chlorophyceae. Fish Investig. 1959, 4, 1-74. 
32. Parke, M.; Manton, I. The specific identity of the algal symbiont in Convoluta roscoffensis. J. Mar. Biol. Assoc. UK 1967, 47, 445-464. [CrossRef]

33. Melkonian, M. An ultrastructural study of the flagellateTetraselmis cordiformis Stein (Chlorophyceae) with emphasis on the flagellar apparatus. Protoplasma 1979, 98, 139-151. [CrossRef]

34. Hori, T.; Norris, R.E.; Chihara, M. Studies on the ultrastructure and taxonomy of the genus Tetraselmis (Prasinophyceae). I. Subgenus Tetraselmis. Bot. Mag. Shokubutsu Gaku Zasshi 1982, 95, 49-61. [CrossRef]

35. Hori, T.; Norris, R.E.; Chihara, M. Studies on the ultrastructure and taxonomy of the genus Tetraselmis (Prasinophyceae). III. Subgenus Parviselmis. Bot. Mag. Shokubutsu Gaku Zasshi 1986, 99, 123-135. [CrossRef]

36. Moestrup, Ø.; Throndsen, J. Light and electron microscopical studies on Pseudoscourfieldia marina, a primitive scaly green flagellate (Prasinophyceae) with posterior flagella. Can. J. Bot. 1988, 66, 1415-1434. [CrossRef]

37. Lee, H.-J.; Hur, S.-B. Genetic relationships among multiple strains of the genus Tetraselmis based on partial 18S rDNA sequences. Algae 2009, 24, 205-212. [CrossRef]

38. El-Kassas, H.Y.; El-Sheekh, M.M. Induction of the synthesis of bioactive compounds of the marine alga Tetraselmis tetrathele (West) Butcher grown under salinity stress. Egypt. J. Aquat. Res. 2016, 42, 385-391. [CrossRef]

39. Pugkaew, W.; Meetam, M.; Yokthongwattana, K.; Leeratsuwan, N.; Pokethitiyook, P. Effects of salinity changes on growth, photosynthetic activity, biochemical composition, and lipid productivity of marine microalga Tetraselmis suecica. J. Appl. Phycol. 2019, 31, 969-979. [CrossRef]

40. Becker, D.; Becker, B.; Satir, P.; Melkonian, M. Isolation, purification, and characterization of flagellar scales from the green flagellateTetraselmis striata (Prasinophyceae). Protoplasma 1990, 156, 103-112. [CrossRef]

41. Arora, M.; Anil, A.C.; Leliaert, F.; Delany, J.; Mesbahi, E. Tetraselmis indica (Chlorodendrophyceae, Chlorophyta), a new species isolated from salt pans in Goa, India. Eur. J. Phycol. 2013, 48, 61-78. [CrossRef]

42. McLachlan, J.; Parke, M. Platymonas impellucida sp. nov. from Puerto Rico. J. Mar. Biol. Assoc. UK 1967, 47, 723-733. [CrossRef]

43. Mackinder, L.C.; Meyer, M.T.; Mettler-Altmann, T.; Chen, V.K.; Mitchell, M.C.; Caspari, O.; Rosenzweig, E.S.F.; Pallesen, L.; Reeves, G.; Itakura, A. A repeat protein links Rubisco to form the eukaryotic carbon-concentrating organelle. Proc. Natl. Acad. Sci. USA 2016, 113, 5958-5963. [CrossRef]

44. Rosenzweig, E.S.F.; Xu, B.; Cuellar, L.K.; Martinez-Sanchez, A.; Schaffer, M.; Strauss, M.; Cartwright, H.N.; Ronceray, P.; Plitzko, J.M.; Förster, F. The eukaryotic CO2-concentrating organelle is liquid-like and exhibits dynamic reorganization. Cell 2017, 171, 148-162. [CrossRef]

45. Gonzalez, M.A.; Aguayo, P.A.; Inostroza, I.D.L.; Castro, P.A.; Fuentes, G.A.; Gomez, P.I. Ultrastructural and molecular characterization of Tetraselmis strains (Chlorodendrophyceae, Chlorophyta) isolated from Chile/Caracterización ultraestructural y molecular de cepas de Tetraselmis (Chlorodendrophyceae, Chlorophyta) aisladas de Chile. Gayana. Bot. 2015, 72, 47. [CrossRef]

46. Hori, T.; Norris, R.E.; Chihara, M. Studies on the ultrastructure and taxonomy of the genus Tetraselmis (Prasino physeae). II: Subgenus Prasinocladia. Shokubutsugaku Zasshi 1983, 96, 385-392. [CrossRef]

47. Silflow, C.D.; Lefebvre, P.A. Assembly and motility of eukaryotic cilia and flagella. Lessons from Chlamydomonas Reinhardtii. Plant Physiol. 2001, 127, 1500-1507. [PubMed]

48. Wingfield, J.L.; Lechtreck, K.-F. Chlamydomonas basal bodies as flagella organizing centers. Cells 2018, 7, 79. [CrossRef] [PubMed]

49. Melkonian, M.; Robenek, H. The eyespot of the flagellate Tetraselmis cordiformis stein (Chlorophyceae): Structural spezialization of the outer chloroplast membrane and its possible significance in phototaxis of green algae. Protoplasma 1979, 100, 183-197. [CrossRef]

50. Calliari, D.; Antezana, T. Diel feeding rhythm of copepod size-fractions from Coliumo Bay, Central Chile. Sci. Mar. 2001, 65, 269-274. [CrossRef]

51. Melkonian, M.; McFadden, G.I.; Reize, I.B.; Becker, D. Secretion of organic scales in green algae: Secretory products are transported through the Golgi apparatus by cisternal progression. Ber. Der Dtsch. Bot. Ges. 1986, 99, 263-280.

52. Reize, I.; Melkonian, M. Flagellar regeneration in the scaly green flagellate Tetraselmis striata (Prasinophyceae): Regeneration kinetics and effect of inhibitors. Helgoländer Meeresunters. 1987, 41, 149-164. [CrossRef]

53. Fabregas, J.; Abalde, J.; Herrero, C.; Cabezas, B.; Veiga, M. Growth of the marine microalga Tetraselmis suecica in batch cultures with different salinities and nutrient concentrations. Aquaculture 1984, 42, 207-215. [CrossRef]

54. Guillard, R.R.; Ryther, J.H. Studies of marine planktonic diatoms: I. Cyclotella nana Hustedt, and Detonula confervacea (Cleve) Gran. Can. J. Microbiol. 1962, 8, 229-239. [CrossRef] [PubMed]

55. Medlin, L.; Elwood, H.J.; Stickel, S.; Sogin, M.L. The characterization of enzymatically amplified eukaryotic 16S-like rRNA-coding regions. Gene 1988, 71, 491-499. [CrossRef]

56. Litaker, R.W.; Vandersea, M.W.; Kibler, S.R.; Reece, K.S.; Stokes, N.A.; Steidinger, K.A.; Millie, D.F.; Bendis, B.J.; Pigg, R.J.; Tester, P.A. Identification of Pfiesteria Piscicida (Dinophyceae) and Pfiesteria-Like Organisms Using Internal Transcribed SpacerSpecific PCR Assays 1. J. Phycol. 2003, 39, 754-761. [CrossRef]

57. Weekers, P.; Gast, R.J.; Fuerst, P.A.; Byers, T.J. Sequence variations in small-subunit ribosomal RNAs of Hartmannella vermiformis and their phylogenetic implications. Mol. Biol. Evol. 1994, 11, 684-690.

58. Giovannoni, S.J.; DeLong, E.F.; Olsen, G.J.; Pace, N.R. Phylogenetic group-specific oligodeoxynucleotide probes for identification of single microbial cells. J. Bacteriol. 1988, 170, 720-726. [CrossRef] 
59. Daugbjerg, N.; Hansen, G.; Larsen, J.; Moestrup, Ø. Phylogeny of some of the major genera of dinoflagellates based on ultrastructure and partial LSU rDNA sequence data, including the erection of three new genera of unarmoured dinoflagellates. Phycologia 2000, 39, 302-317. [CrossRef]

60. Pruesse, E.; Peplies, J.; Glöckner, F.O. SINA: Accurate high-throughput multiple sequence alignment of ribosomal RNA genes. Bioinformatics 2012, 28, 1823-1829. [CrossRef]

61. Kumar, S.; Stecher, G.; Tamura, K. MEGA7: Molecular evolutionary genetics analysis version 7.0 for bigger datasets. Mol. Biol. Evol. 2016, 33, 1870-1874. [CrossRef]

62. Reichenbach, H.G. Conspectus Regni Vegetabilis per Gradus Naturales Evoluti; Carolum Cnobloch: Leipzig, Germany, 1828.

63. Oltmanns, F. Morphologie und Biologie der Algen. 1. Spezieller Teil; Verlag von Gustav Fischer: Jena, Germany, $1904 ;$ p. 733. 